\title{
Structural Analysis of Brittle Failure Structures in Spi Res Anticline - Northern Iraq
}

\author{
Ibrahim S. Aljumaily Nawal M. A. Othman \\ Department of Geology \\ College of Science \\ University of Mosul
}

(Received 7/8/2011, Accepted 12/10/2011)

\begin{abstract}
The present study involves different aspect of brittle failure structures at Spi Res Anticline within the foreland fold belt of north Iraq. It aims to decipher whether the late Cretaceous orogenic episode has any fracturing consequence to the rock sequence of this period at investigated area. This was accomplished by comparison of various fracture modes between Upper Cretaceous and Tertiary rock sequence exposed at studied area. The study area is prevailed with widespread joints and tabular veins, little mesoscopic faults and scarce of pressure solution surfaces (stylolite). Joint analysis showed two extensional sets (ac and bc) and three shear systems (hko, hol and okl). However, hko acute about $\mathbf{a}$ and $\mathbf{b}$ system was prevailed and followed by ac and bc sets. The openings of most of joint sets were filled later by calcareous or siliceous precipitations without any kinematic indications, some refers to extension normal with vein walls and for a single growth episode. A little number of striated mesoscopic faults were registered throughout both Cretaceous and Tertiary rocks in study area. Most of them are reverse, others are normal and strike slip. Further, two sets of stylolite seams were found scarcely, peaks of the first oriented parallel with the bedding dip, whereas those of the other set trended parallel to bedding strike. The kinematic analysis of mesoscopic faults and shear joints in study area gave a number of compressive and strike slip stress tensors. The maximum horizontal stress $\left(\boldsymbol{\delta}_{\max }\right)$ of these tensors lie in N-S, NE-SW, E-W and NW-SE general trends. Accordingly, they were organized into two compressive tectonic regimes. One representing the component normal to the orogenic front, acted in N-S and NE-SW directions. Whereas the other representing the component parallel with the orogenic front, acted in E-W and NW-SE directions. Both components were resulted from oblique collision of Arabian and Eurasian plates. However, these two compressive tectonic regimes are supported by a couple sets of stylolites with their peaks either normal or parallel to the trend of Spi Res Anticline. No brittle failure structures belonging to orogenic episode of
\end{abstract}


Late Cretaceous were recognized in the Upper Cretaceous succession of study area in the present investigation.

Keywords: Spi Res, joint, vein, stylolite, tensor, fault.

$$
\begin{aligned}
& \text { التحليل التركيبي لتراكيب التكسر الهش في طية سبي ريس } \\
& \text { المحدبة - شمالي العراق } \\
& \text { نوال محمد علي عثمان } \\
& \text { إبراهيم سعد الجميلي } \\
& \text { قسم علوم الأرض العلدة المعلم }
\end{aligned}
$$

الملخص

تتضمن هذه الدراسة النواحي المختلفة لتراكيب التكسر الهش في طية سبي ريس المحدبة ضمن حزام طيات

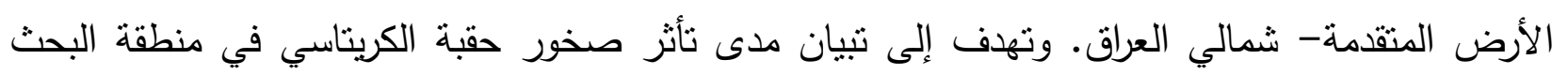
بتشوه التكسر لطور نهاية الكريتاسي من الاوروجيني. ولغرض بلوغ هذه الغاية الغانة، فقد أجريت مقارنة شاملة

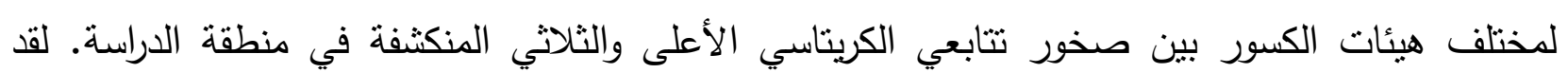

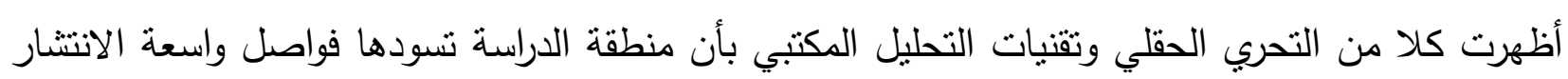

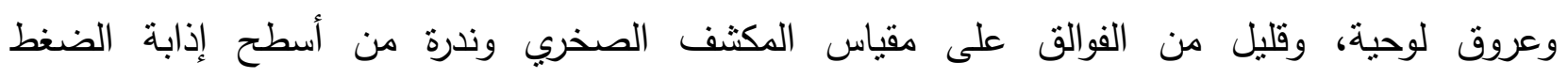

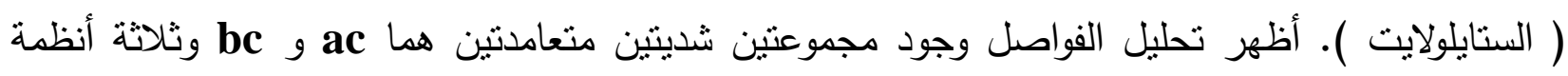

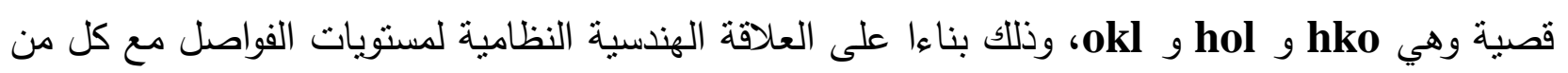
مستويات النطبق ومحور الطية. وكانت درجات الثيوع لهذه الفواصل على النحو الأتي: hko الحاد حول

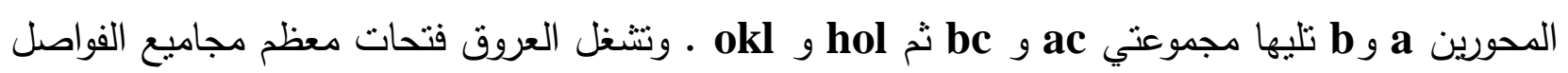

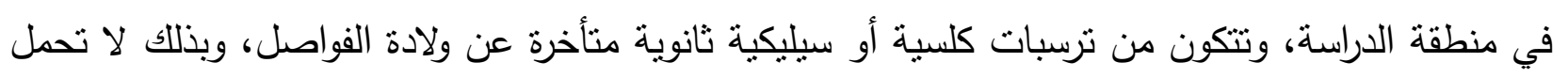
أية أدلة حركية باستثناء القليل منها الذي يثير إلى تمدد منعامد على جداري العرق ولمرحلة نمو أحادية. تم

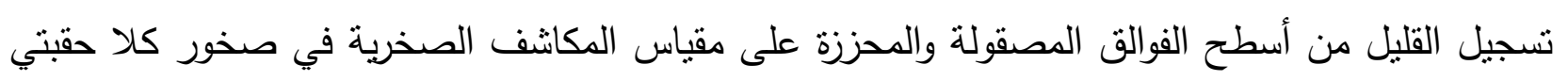

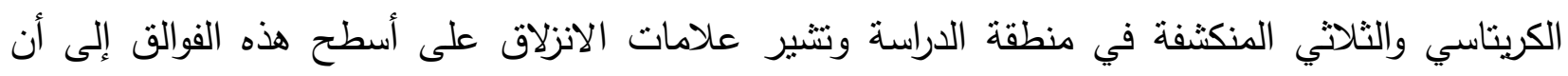

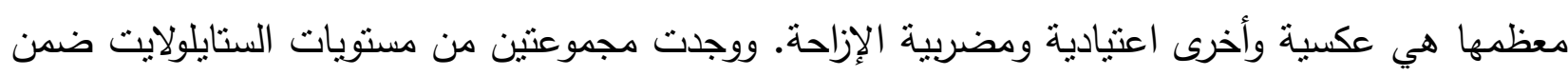

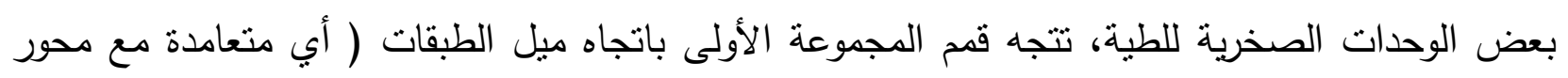
الطية)، فيما تتجه قمم المجموعة الأخرى بموازاة مضرب الطبقات ( أي بموازاة محور الطية ). التحليل الحركي للفوالق والفواصل القصية في منطقة الدراسة أسفر عن عدد من تتسرات الإجهاد الإنضغاطية 
والمضربية الإزاحة إضافة إلى أنواع ثانوية طبقا لنسب الإجهاد الخاصة لكل من ثلك التتسرات. إن محور الإجهاد الأفقي الأعظم الإحة $\boldsymbol{\delta}_{\text {max }}$ NW-SE المتعامدة مع جبهة الأوروجيني وكان فاعلا باتجاهي N-S و NE-SW. فيما الآخر يمنل المركبة الموازية لجبهة الأوروجيني وكان فاعلا باتجاهي E-W و NW-SE. كلا المركبتين نتجتا من التصادم المائل بين الطبقين التكتونيين العربي والأوراسي. إن تمييز هذين النظامين التكتونيين الانضخاطيين قد تعزز بنتخيص

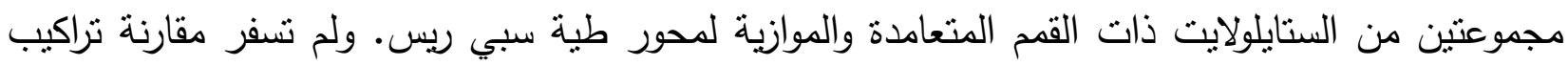

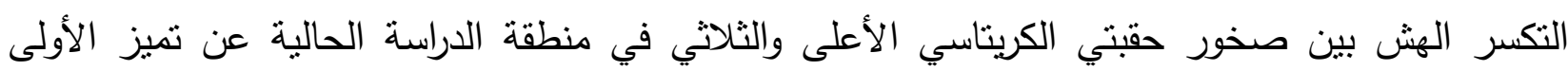
بتراكيب من التكسر عائدة لطور نهاية الكريتاسي للأوروجيني.

\section{INTRODUCTION}

The purpose of this study is to compare modes of brittle failure structures between Cretaceous and Tertiary successions exposing in Spi Res Anticline, and to elucidate their kinematic and dynamic implications.

Spi Res Anticline is one of two culminations within the huge Bekhair structure that extends $71 \mathrm{~km}$ in the high fold zone of northern Iraq. The general trend of Bekhair structure varies from Zagros trend (NW-SE) in its eastern part (Zawita -Geli Zakho) to Taurus trend (E-W) in its most western part (Al-Azzawi and Al-Hubiti, 2009) (Fig. 1).

The length and maximum width of Spi Res Anticline reaches about 12 and 3 $\mathrm{km}$. respectively. It is foreland verged with steep SW limb $\left(40^{\circ}\right)$ and gentle NE limb $\left(24^{\circ}\right)$, its axial plane and fold axis attitudes are (106/82) and (286/04) respectively (Fig. 2). Its SE plunge is relatively wide compared with the NW plunge which is in en-echelon arrangement with the other culmination (Gara Baran Anticline) (Fig. 3).

Upper Cretaceous rock units exposed in the core of the anticline are of Bekhme Fm. (limestone, dolomite and dolomitic limestone), Shiranish Fm. (pelagic marl inter bedded with marly limestone). These units are overlain by Tertiary units: they are Paleocene - Lower Eocene Kolosh Fm. (sand, silt, shale and marl), Khurmala Fm. (reefal limestone), Middle Eocene Gercus Fm.(red sand, silt and mud), Upper Eocene Pila Spi Fm.(limestone and dolomitic limestone), Middle Miocene Fatha Fm. claystone with thin limestone and evaporate interbeds) and Upper Miocene Injana Fm. (inter bedding of sandstone, siltstone and claystne) (Fig. 3).

Twenty five observation locations were chosen throughout different structural and stratigraphic domains of the anticline (Fig. 3). At each locality attitudes of bedding and brittle failure structures were measured. Field notes, sketches and photographs were taken for such structures as well. The gathered field data then processed by stereographic technique using available softwares. 
The benefit and significance of using brittle failure structures in structural analysis and tectonic raveling of regions is well documented by numerous authors like (Hancock, 1985; Ble`s and Feuga, 1986; Angelier, 1994; Ramsay and Huber, 1987; Van der Pluijm and Marshak, 2004; Georg Mandl, 2005; Twiss and Moores, 2007).

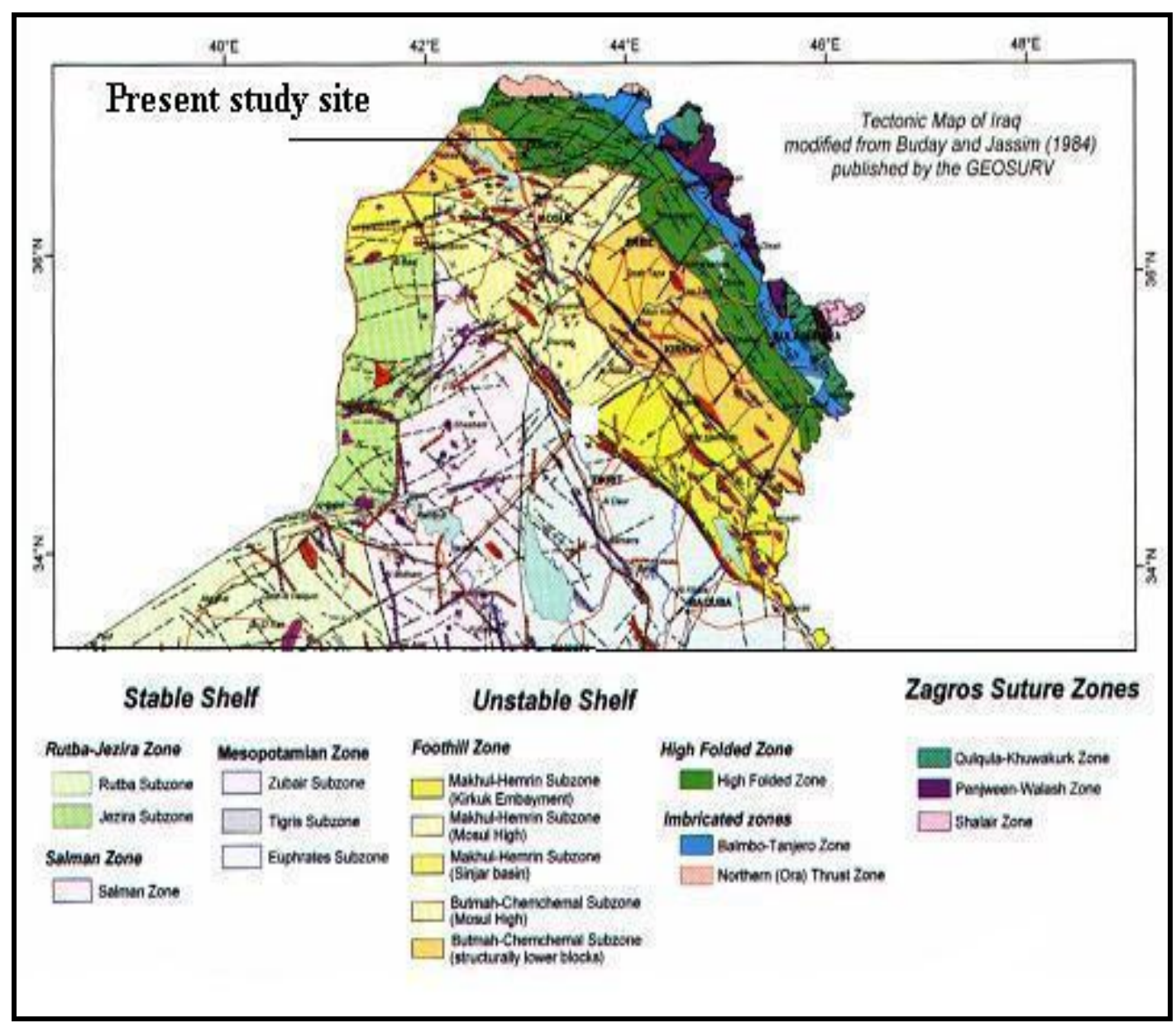

Fig. 1: Tectonic Subdivision Map of North Iraq Showing Location of Study Area ( Jassim and Goff, 2006).

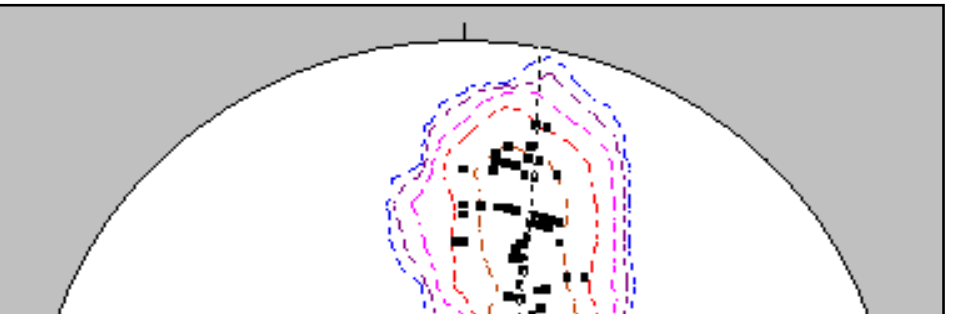




\section{JOINT SETS AND SYSTEMS}

The prevailing joints in study area are hko acute about $\mathbf{a}$ and b systems. They commonly appear as individual sets and occasionally as conjugate sets. Orthogonal ac and bc sets come in second rank prevalence. However, the least prevailed joints are hol acute about $\mathbf{a}$ and $\mathbf{c}$, and okl acute about $\mathbf{b}$ and $\mathbf{c}$ (plate: photos 1, 2, 3; Fig. 4; Table 1). According to their geometrical relationship with the anticline trend and local bedding attitudes, they were divided kinematically into tension (ac and bc) sets and shear systems (hko, hol and okl) (Hancock, 1985).

The prevailing joint sets and systems are the product of regional stress field regime resulted from Arabian -Eurasian plate collision. Such stress field was acting in pulses, each pulse consisting of direct compression succeeded by relaxation. In direct compression, the maximum horizontal compressive axis oriented normally to orogenic front (fold trend), and hence led to development of hko acute about a shear joints accompanied with ac tension joints. Whereas in relaxation episode of each tectonic pulse, the maximum horizontal compressive axis oriented parallel to orogenic front, and led to development of hko acute about $\mathbf{b}$ shear joints accompanied with be tension joints. The less prevailed joint systems (hol and okl) seem to be related to the local stress field that developed during folding (i.e hinge and limb deformation fracturing, Ble`s and Feuga, 1986).

The pulsating manner of jointing caused interference among joint sets and systems formed in study area, and hence inconsistent relative age relationship arisen between such joint sets and systems. 


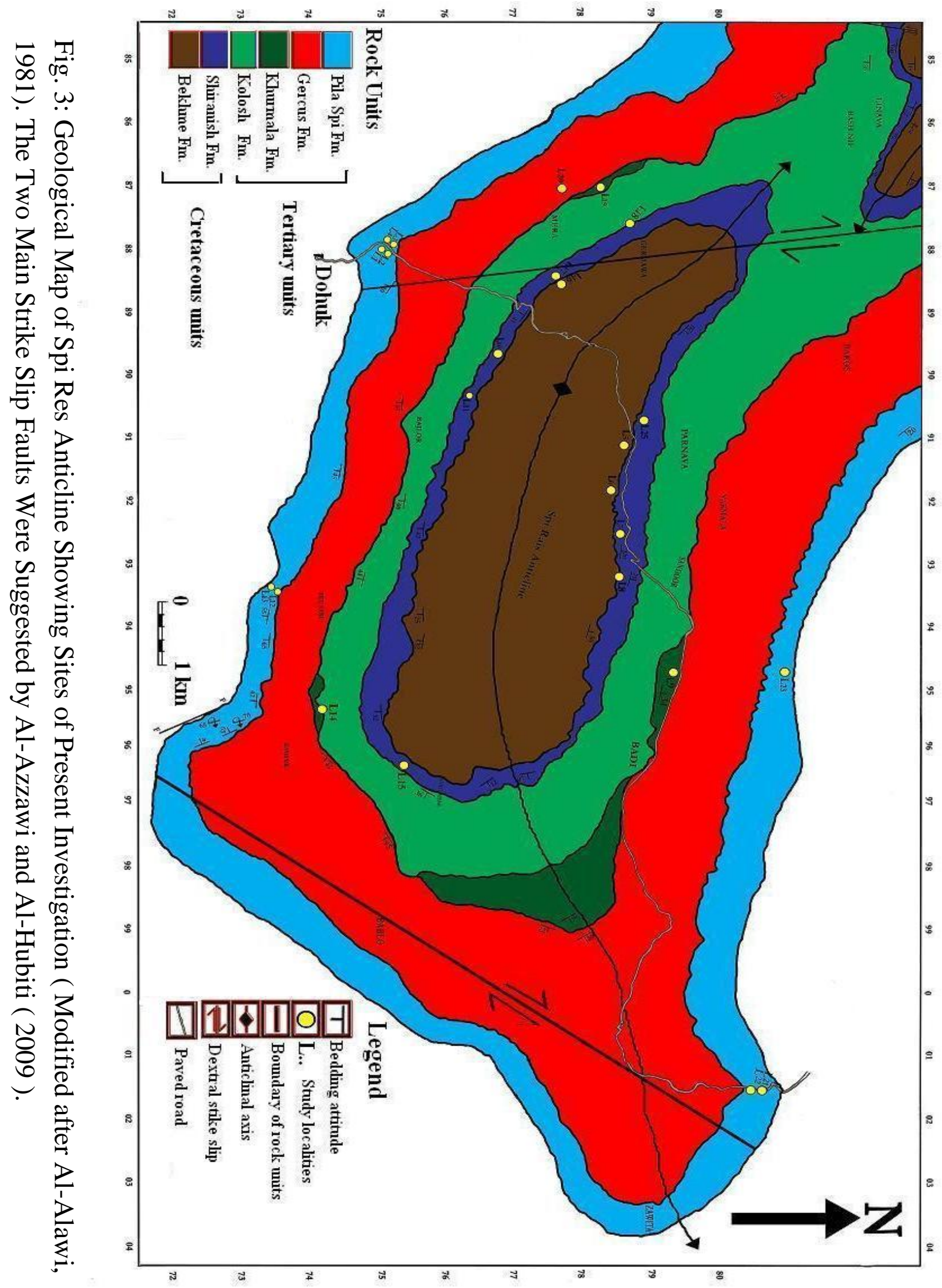


Table 1: Measured Joints in Different Locations and Rock Units of Spi Res Anticline, as Classified Into Sets and Systems, Numbers 1 and 2 Rrefer to Complimentary Sets Within Each System.

\begin{tabular}{|c|c|c|c|c|c|c|c|c|c|c|c|c|c|c|c|c|c|}
\hline \multirow{2}{*}{ 节 } & \multirow{2}{*}{ } & \multirow{2}{*}{ 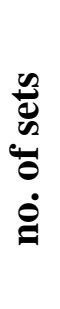 } & \multirow[b]{2}{*}{ שี } & \multirow[b]{2}{*}{ 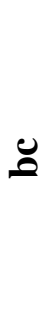 } & \multicolumn{2}{|c|}{ hko>a } & \multicolumn{2}{|c|}{ hko>b } & \multicolumn{2}{|c|}{ hol $>\mathbf{a}$} & \multicolumn{2}{|c|}{ hol $>$ c } & \multicolumn{2}{|c|}{ okl $\mathbf{l}>\mathbf{b}$} & \multicolumn{2}{|c|}{ okl $>c$} & \multirow{2}{*}{ 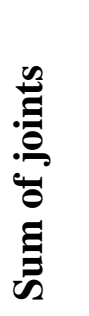 } \\
\hline & & & & & 1 & 2 & 1 & 2 & 1 & 2 & 1 & 2 & 1 & 2 & 1 & 2 & \\
\hline $\mathbf{L 1}$ & Pila Spi & 10 & 10 & - & $\begin{array}{l}1 \\
2\end{array}$ & $\begin{array}{l}1 \\
8\end{array}$ & 5 & 18 & - & - & 6 & 3 & 3 & - & 2 & 5 & 82 \\
\hline $\mathbf{L 2}$ & Avana & 6 & 8 & - & $\begin{array}{l}2 \\
2\end{array}$ & 9 & 20 & 3 & - & - & - & 4 & - & - & - & - & 66 \\
\hline $\mathbf{L 3}$ & Avana & 10 & 12 & 3 & $\begin{array}{l}2 \\
6\end{array}$ & 5 & 1 & 7 & - & - & 2 & 4 & 1 & - & - & 20 & 81 \\
\hline L4 & Pila Spi & 10 & 11 & 2 & $\begin{array}{l}1 \\
5\end{array}$ & $\begin{array}{l}2 \\
0\end{array}$ & 7 & 13 & - & - & - & 2 & 2 & - & 4 & 8 & 84 \\
\hline L5 & Bekhme & 2 & - & - & $\begin{array}{l}7 \\
4\end{array}$ & - & 40 & - & - & - & - & - & - & - & - & - & 114 \\
\hline L6 & Bekhme & 5 & 2 & - & $\begin{array}{l}1 \\
3\end{array}$ & $\begin{array}{l}6 \\
6\end{array}$ & 15 & 8 & - & - & - & - & - & - & - & - & 104 \\
\hline L7 & Shiranish & 4 & - & - & $\begin{array}{l}1 \\
8\end{array}$ & $\begin{array}{l}1 \\
8\end{array}$ & 13 & 31 & - & - & - & - & - & - & - & - & 80 \\
\hline L8 & Shiranish & 6 & - & - & $\begin{array}{l}1 \\
6\end{array}$ & $\begin{array}{l}1 \\
5\end{array}$ & 6 & 44 & - & - & 2 & - & - & 1 & - & - & 84 \\
\hline L9 & Khurmala & 9 & 5 & - & $\begin{array}{l}2 \\
2\end{array}$ & $\begin{array}{l}4 \\
1\end{array}$ & 33 & 23 & - & - & $\begin{array}{l}1 \\
3\end{array}$ & 3 & - & - & 1 & 1 & 142 \\
\hline L10 & Shiranish & 8 & 33 & 2 & $\begin{array}{l}1 \\
0\end{array}$ & 7 & 6 & 4 & - & - & 6 & - & - & - & - & 2 & 70 \\
\hline L11 & Shiranish & 10 & 12 & 5 & $\begin{array}{l}1 \\
2\end{array}$ & 8 & 9 & 11 & - & - & 7 & 1 & - & - & 2 & 4 & 71 \\
\hline L12 & Avana & 11 & 18 & 3 & 7 & $\begin{array}{l}1 \\
4\end{array}$ & 10 & 5 & - & - & 3 & 1 & 4 & 4 & - & 8 & 77 \\
\hline L13 & Pila Spi & 13 & 29 & - & $\begin{array}{l}2 \\
6\end{array}$ & $\begin{array}{l}2 \\
8\end{array}$ & 4 & 11 & 3 & 3 & 2 & 5 & 2 & 1 & 1 & 10 & 125 \\
\hline
\end{tabular}


Table 1: Cont.

\begin{tabular}{|c|c|c|c|c|c|c|c|c|c|c|c|c|c|c|c|c|c|}
\hline \multirow{2}{*}{ } & \multirow{2}{*}{ 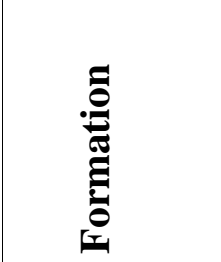 } & \multirow{2}{*}{$\begin{array}{l}\frac{n}{e_{0}} \\
\frac{0}{0} \\
\dot{0} \\
\dot{0}\end{array}$} & \multirow[b]{2}{*}{ שֶ } & \multirow[b]{2}{*}{ こ } & \multicolumn{2}{|c|}{ hko>a } & \multicolumn{2}{|c|}{ hko>b } & \multicolumn{2}{|c|}{ hol>a } & \multicolumn{2}{|c|}{ hol>c } & \multicolumn{2}{|c|}{ okl $>$ b } & \multicolumn{2}{|c|}{ okl >c } & \multirow[t]{2}{*}{ 훙 } \\
\hline & & & & & 1 & 2 & 1 & 2 & 1 & 2 & 1 & 2 & 1 & 2 & 1 & 2 & \\
\hline L14 & Khurmala & 6 & 11 & 8 & 13 & 8 & 17 & 22 & - & - & - & - & - & - & - & - & 79 \\
\hline L15 & Shiranish & 8 & 3 & 4 & 12 & 5 & 4 & 22 & - & - & 7 & - & 2 & - & - & - & 59 \\
\hline L16 & Bekhme & 11 & 34 & 16 & 28 & 53 & 36 & 52 & 1 & - & 9 & 5 & - & - & 18 & 13 & 265 \\
\hline L17 & Shiranish & 9 & 22 & 3 & 6 & 39 & 16 & 28 & - & - & 7 & - & 9 & - & - & 9 & 139 \\
\hline L18 & Shiranish & 7 & 5 & 1 & 13 & 25 & 23 & 19 & - & - & - & - & - & - & 2 & - & 88 \\
\hline L19 & Khurmala & 8 & 14 & 6 & 19 & 16 & 24 & 8 & - & - & - & - & - & - & 3 & 2 & 92 \\
\hline L21 & Pila Spi & 9 & 15 & - & 31 & 39 & 21 & 8 & - & - & 4 & 1 & - & - & 3 & 9 & 131 \\
\hline L22 & Pila Spi & 8 & 7 & 1 & 8 & 15 & 12 & 6 & - & - & - & 1 & - & - & - & 7 & 57 \\
\hline $\mathbf{L 2 3}$ & Pila Spi & 7 & 7 & 2 & 21 & 10 & 12 & 14 & - & - & - & - & - & - & - & 3 & 69 \\
\hline L24 & Bekhme & 9 & 20 & 13 & 9 & 8 & 11 & - & - & 2 & 2 & - & - & 2 & - & 6 & 49 \\
\hline \multicolumn{3}{|c|}{ Sum of locations } & 워 & $m$ & $\approx$ & ป & $\ddot{N}$ & $\vec{\sim}$ & $N$ & $\sim$ & $n$ & $a$ & $r$ & $\nabla$ & $a$ & $n$ & \\
\hline \multicolumn{3}{|c|}{ Sum of joints } & $\sqrt{6}$ & $\stackrel{\bullet}{n}$ & $\stackrel{m}{q}$ & 安 & $\stackrel{n}{n}$ & in & $\nabla$ & $n$ & 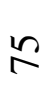 & 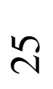 & 2 & $\infty$ & లి & $\hat{0}$ & 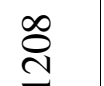 \\
\hline \multicolumn{3}{|c|}{ Prevalence rank } & \multicolumn{2}{|c|}{ Third } & \multicolumn{2}{|c|}{ First } & \multicolumn{2}{|c|}{ Second } & \multicolumn{2}{|c|}{ Seventh } & \multicolumn{2}{|c|}{ Fifth } & \multicolumn{2}{|c|}{ Sixth } & \multicolumn{2}{|c|}{ Fourth } & \\
\hline
\end{tabular}




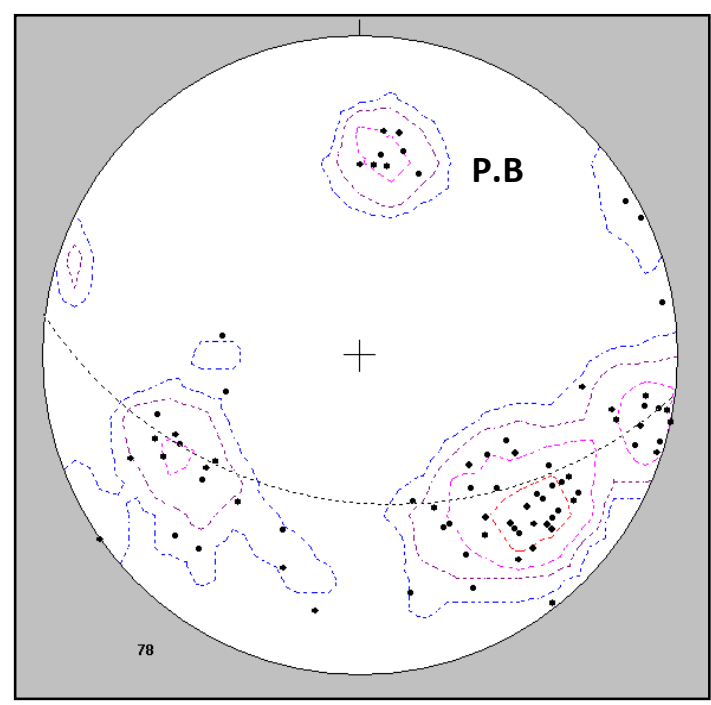

L2 Avana

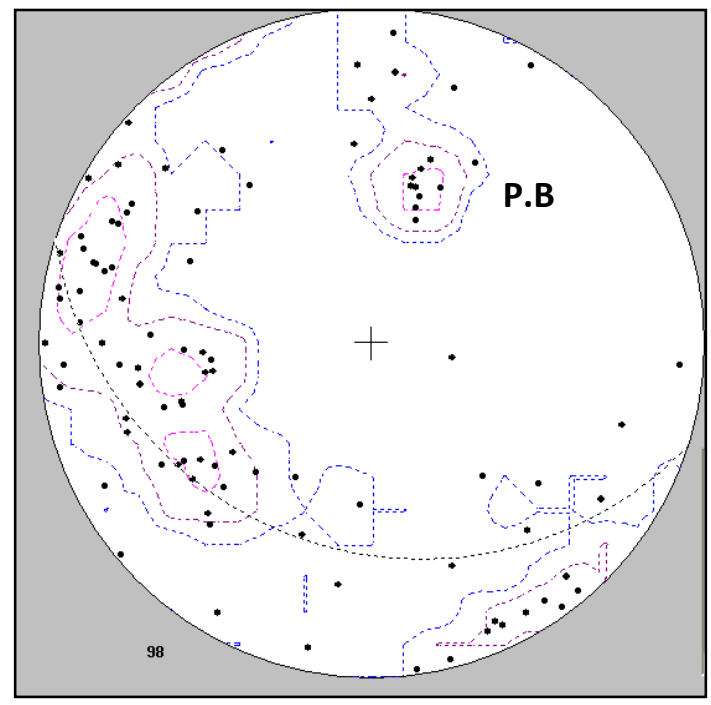

L4 Pila Spi

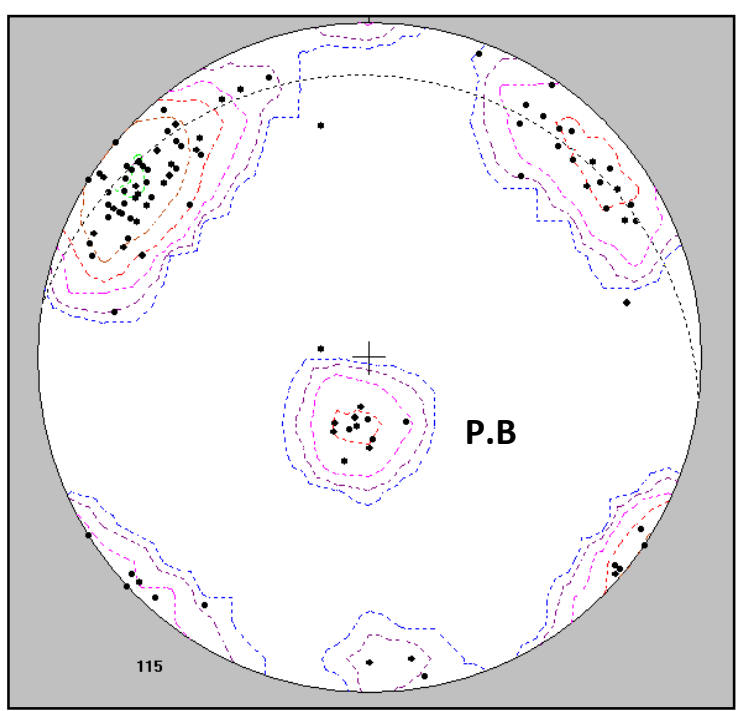

L6 Bekhme

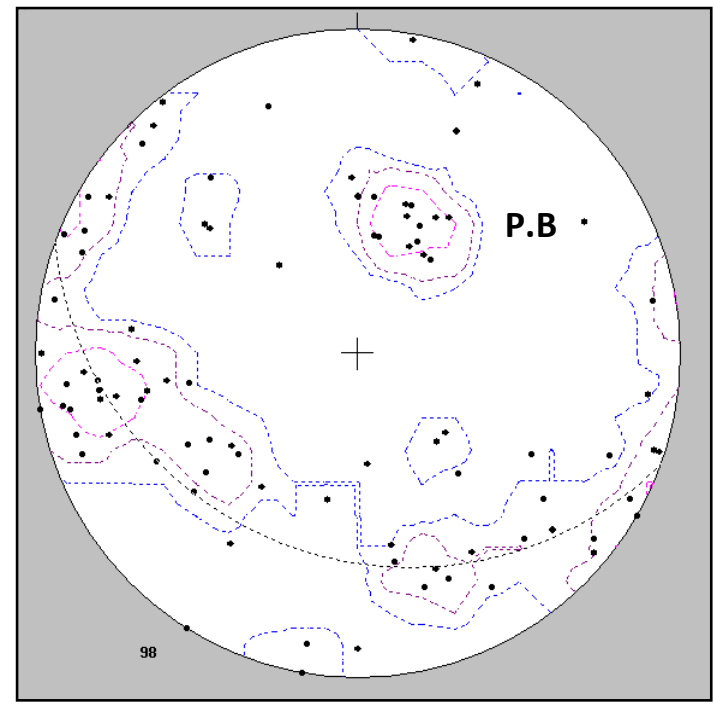

L1 Pila Spi

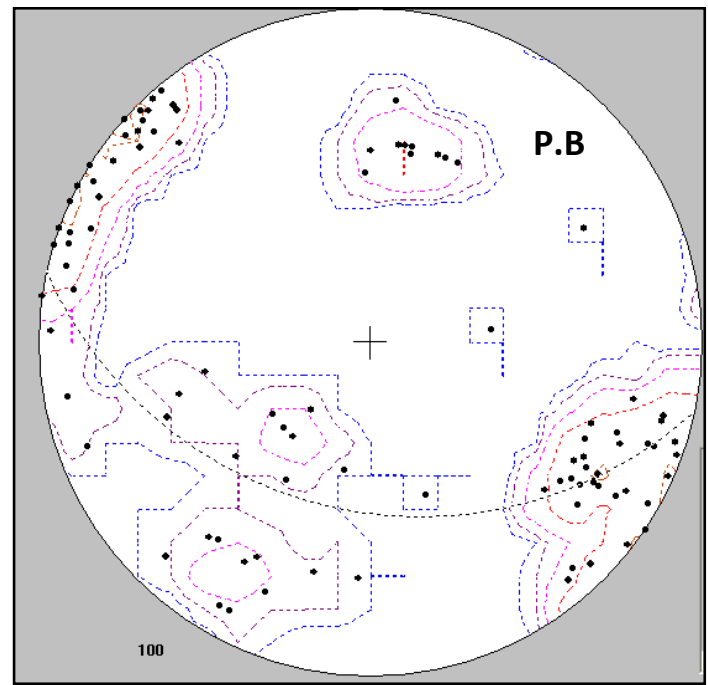

L3 Avana

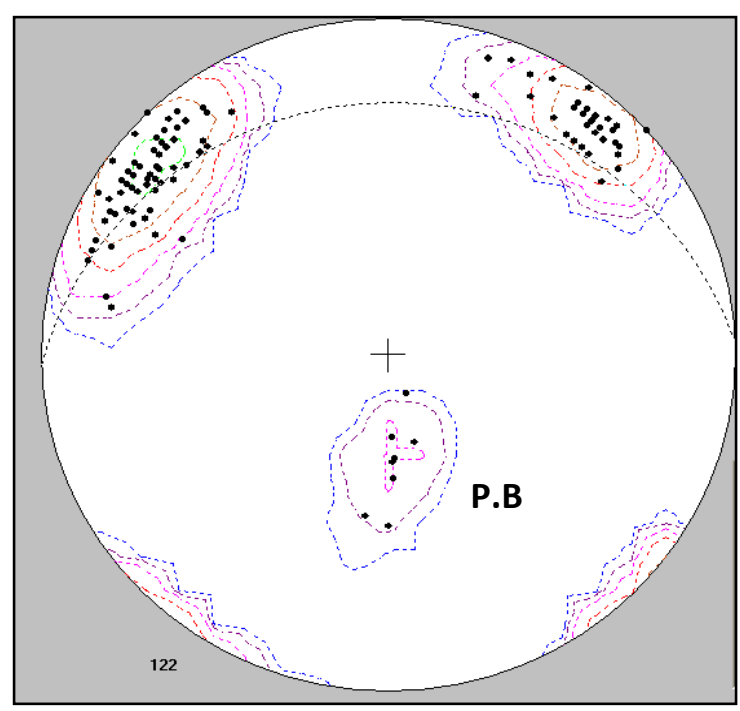

L5 Bekhme

Fig. 4: Contoured Stereonets of Joints Poles in Various Structural Domains of Spi Res Anticline and within Different Rock Formations. Great Circles Represent Average Bedding Attitude at Respective Localities. P.B Refers to Cluster of Bedding Poles in Each Locality. 
Fig. 4: Cont.

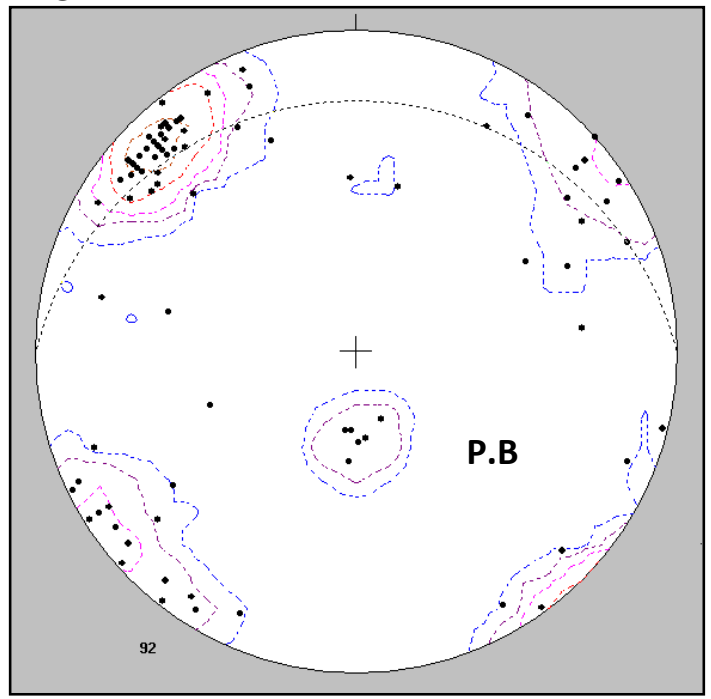

L8 Shiranish

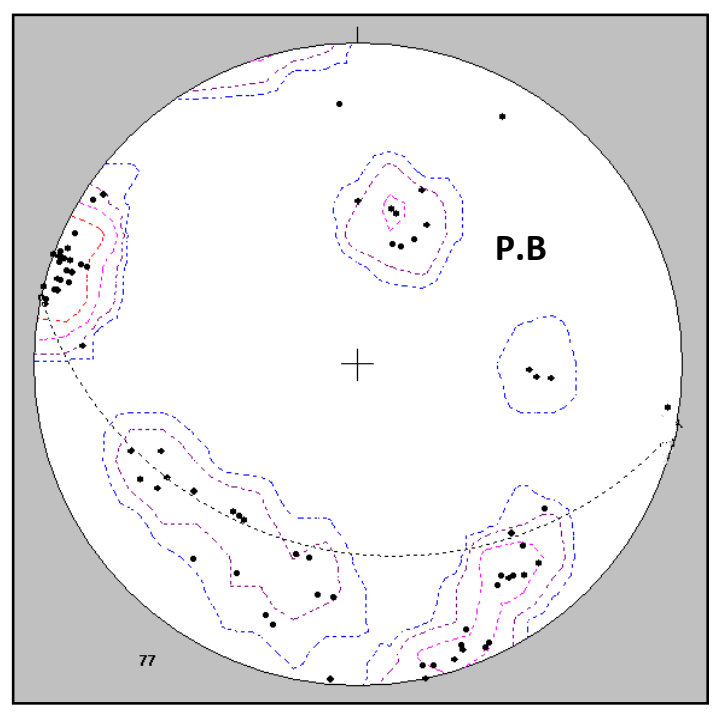

L10 Shiranish

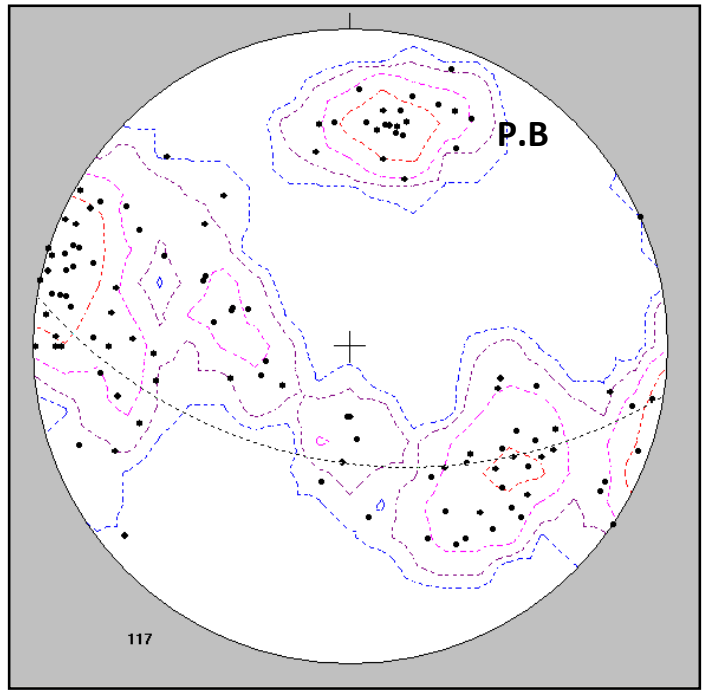

L12 Avanah

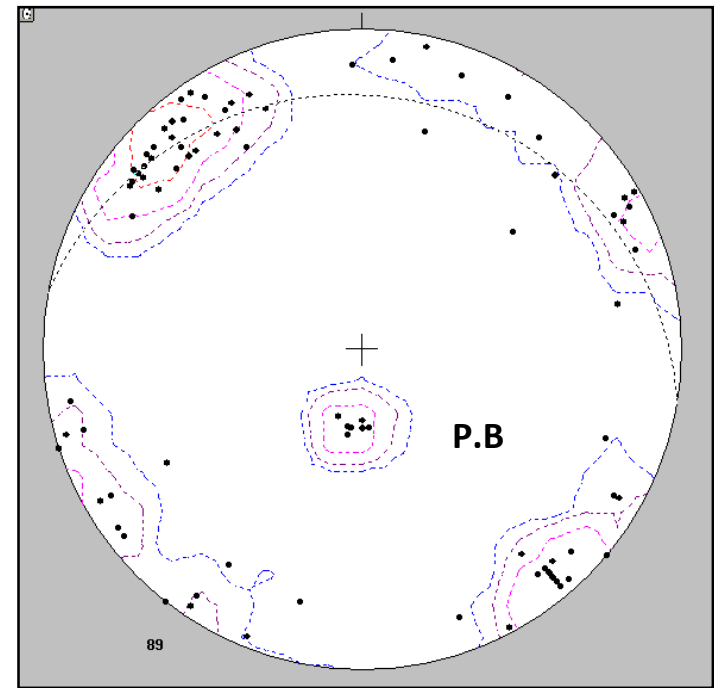

L7 Shiranish

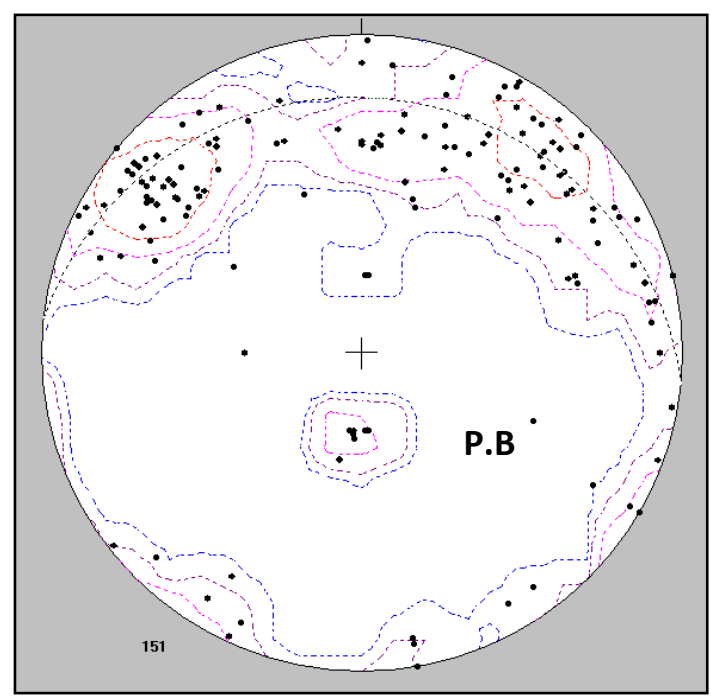

L9 Khurmala

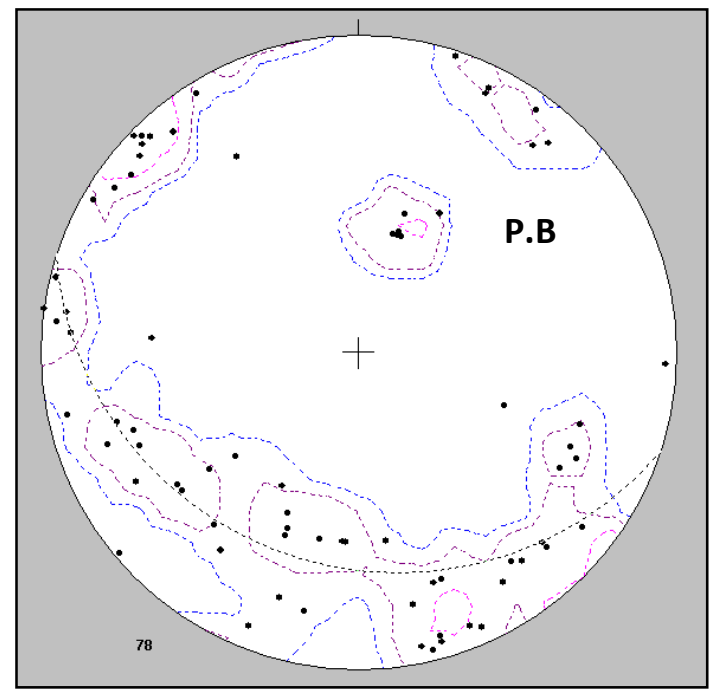

L11 Shiranish 
Fig. 4 : Cont.

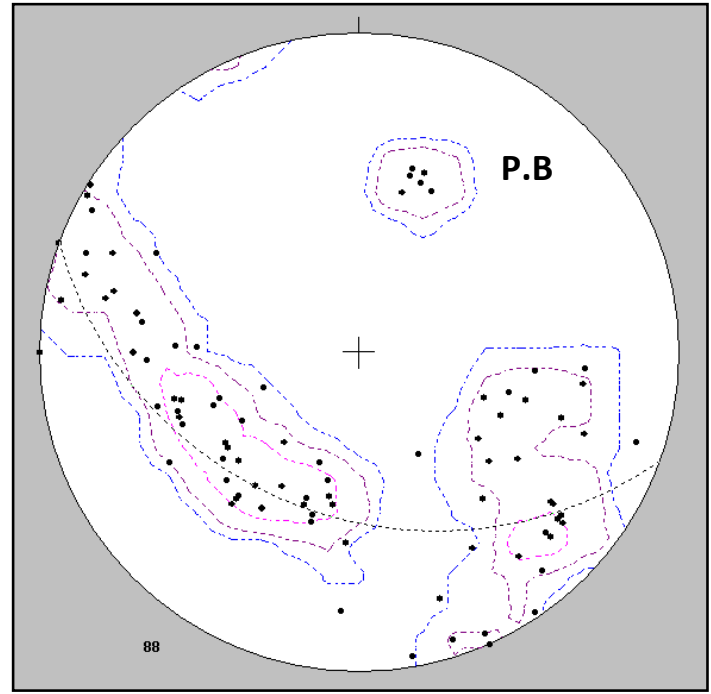

L14 Khurmala

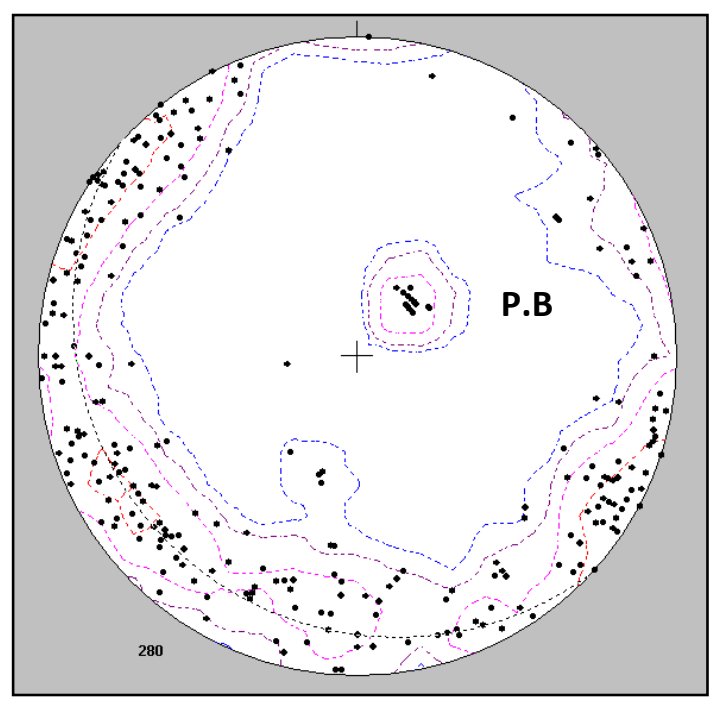

L16 Bekhme

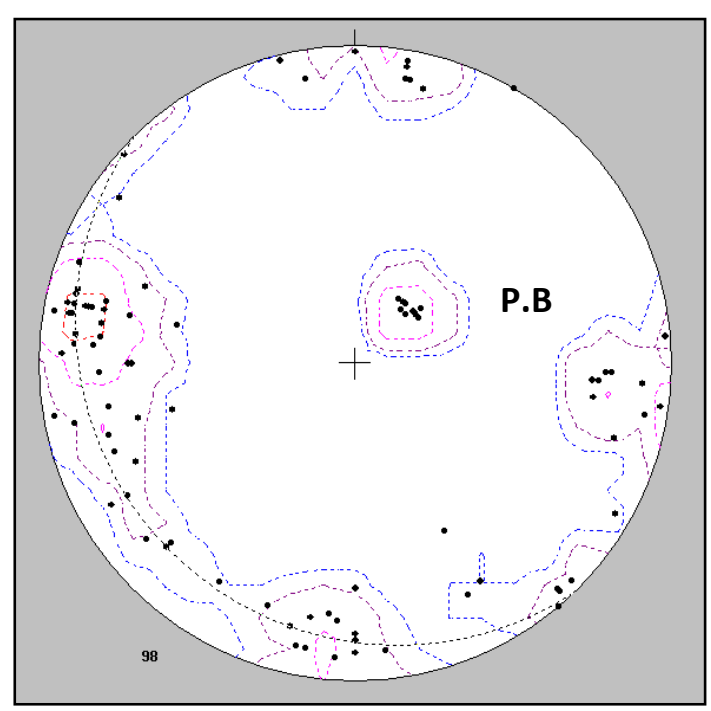

L18 Shiranish

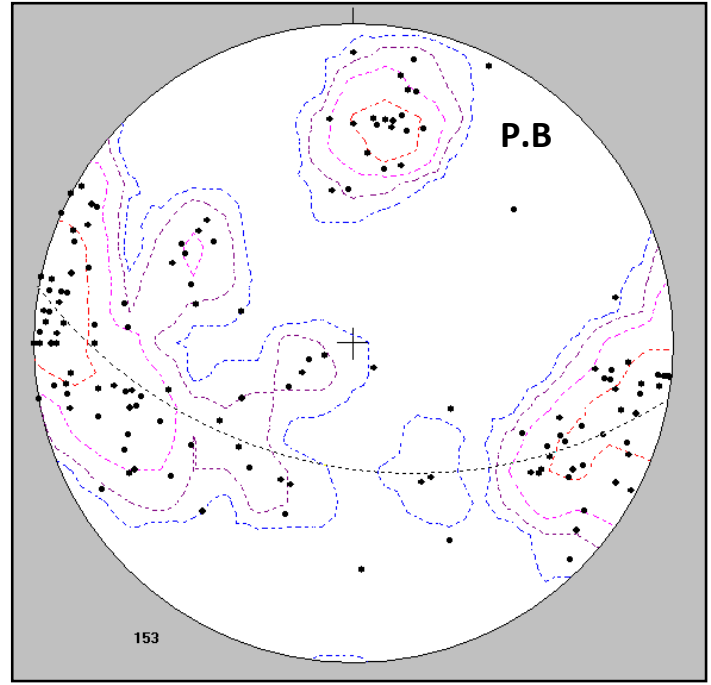

L13 Pila Spi

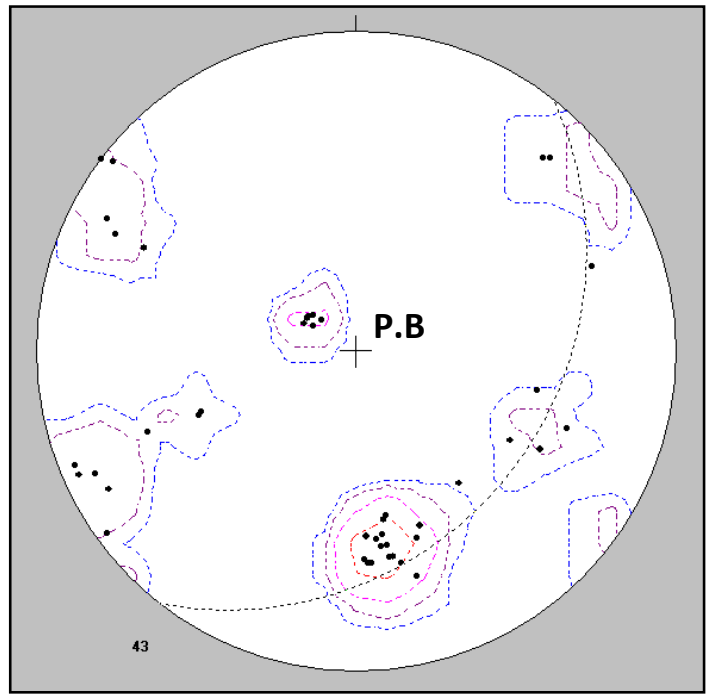

L15 Shiranish

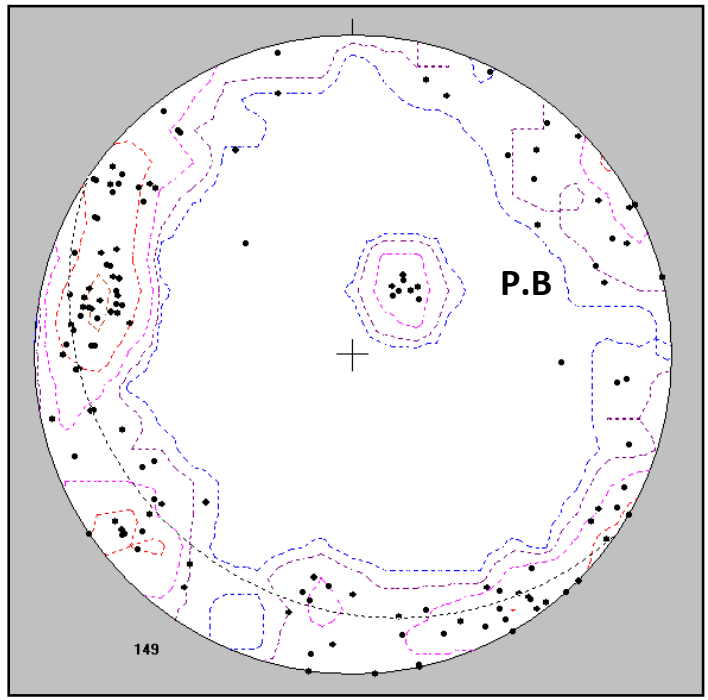

L17 Shiranish 
Fig. 4 : Cont.

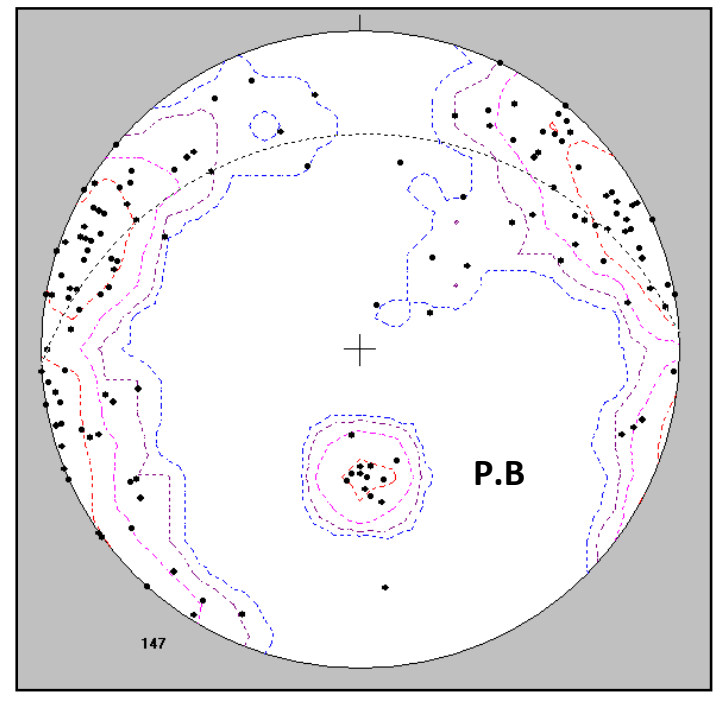

L21 Pila Spi

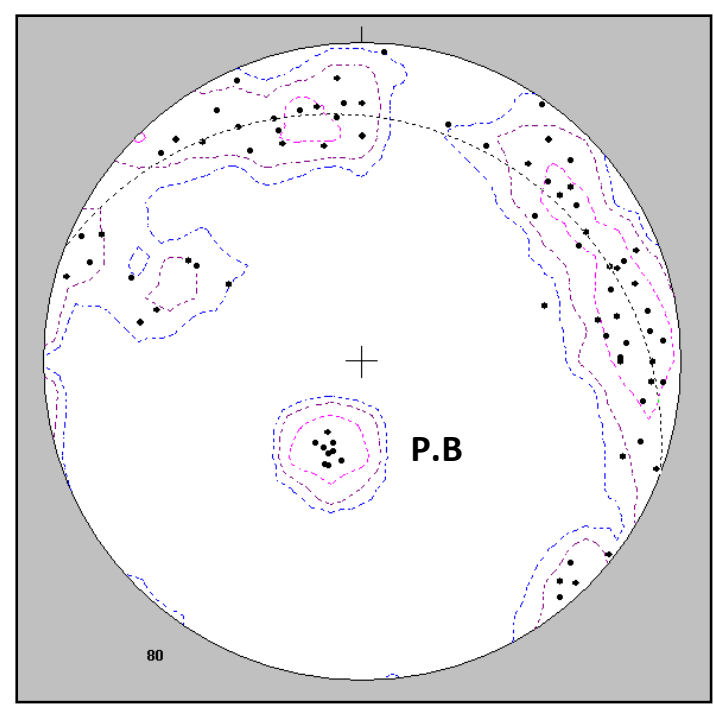

L23 Pila Spi

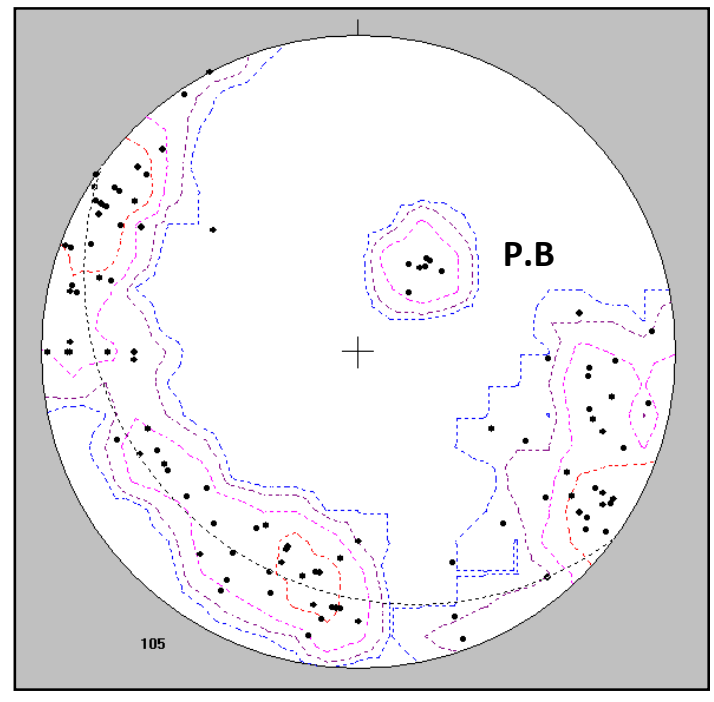

L19 Khurmala

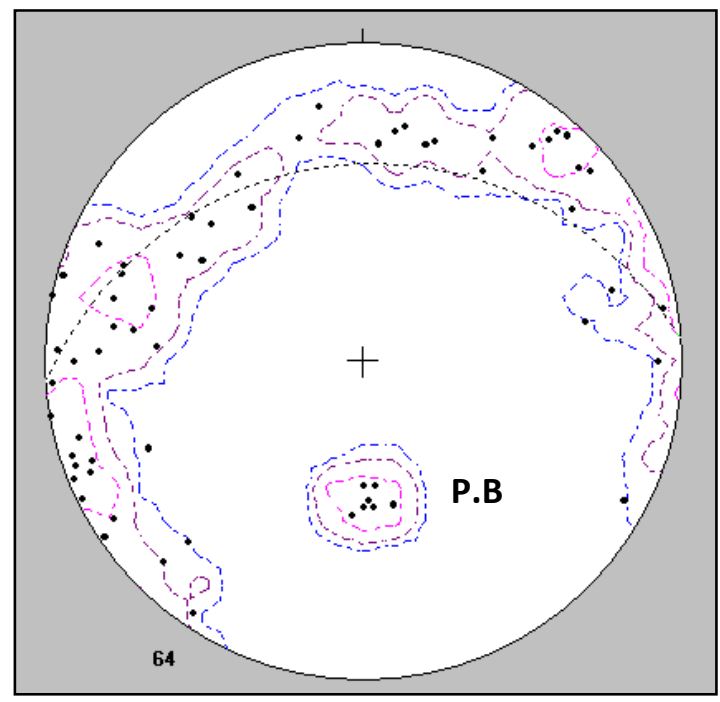

L22 Avanah

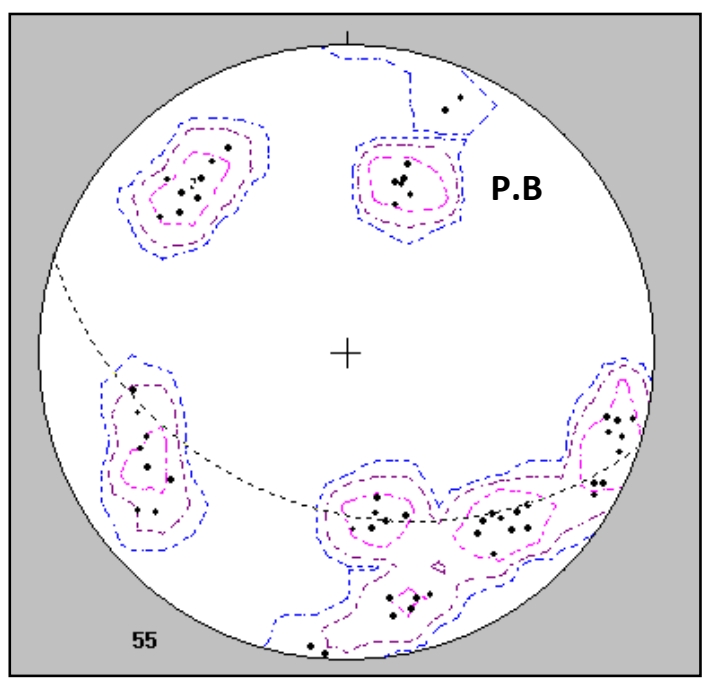

L24 Bekhme 


\section{FAULTS}

Groups of mesoscopic faults were recognized at nine localities of Spi Res Anticline. According to visible slip striations on their surfaces, they have been organized into normal, strike slip and reverse faults (Photos 4, 5, 6, 7).

Geometrically, these mesofaults belong to hko, hol and okl systems (Table 2). The direction and sense of movement on some agree geometrically and kinematically with their accompanied joints. But most of them don't show such agreement, and thus, they may represent reactivated planes. An interesting transtensional mesofault trace observed on a limestone layer top of Pila Spi Fm. at NE limb of the anticline (locality 21). It is a left bend sinistral strike slip fault (Photo 5). The sinistral slip of this fault led to extension in the bend zone, meanwhile the bend of this fault represents releasing step or jog (Ramsay and Huber, 1987 ; Van der Pluijm and Marshak, 2004).

The concentration of a fore mentioned mesofault groups in gully Zawita close to the SE plunge nose of the anticline, and in Garmava valley near its NW plunge nose, may refer to kinematic relationship of these mesofaults with the right lateral strike slip major faults transversal to the anticline trend at these specified locations as interpreted from satellite imagery (Fig. 3).

The vary attitude of mesofaults and their slip lines seem comfortable with the both normal and parallel compressive directions with respect to anticline trend. Such compressive directions with their secondary derived extensions parallel and normal to fold trend were interpreted from joint analysis as well.

A small graben structure found at SW limb of the anticline in Gercus Fm. (locality 19). The two normal mesofaults bounding this graben occupy okl acute about $\mathbf{c}$ system. These normal slip faults may be attributed to extension parallel to the anticline trend during folding, or may be related to the uplift of the anticline.

A set of longitudinal antithetic normal mesofaults (parallel with bedding strike) observed on both limbs of the anticline in Cretaceous rock units occupying hol acute about c system (Photo 4). Such these normal slip mesofaults considered as expression for relaxation episode subnormal to fold hinge during the final uplift of the anticline. 

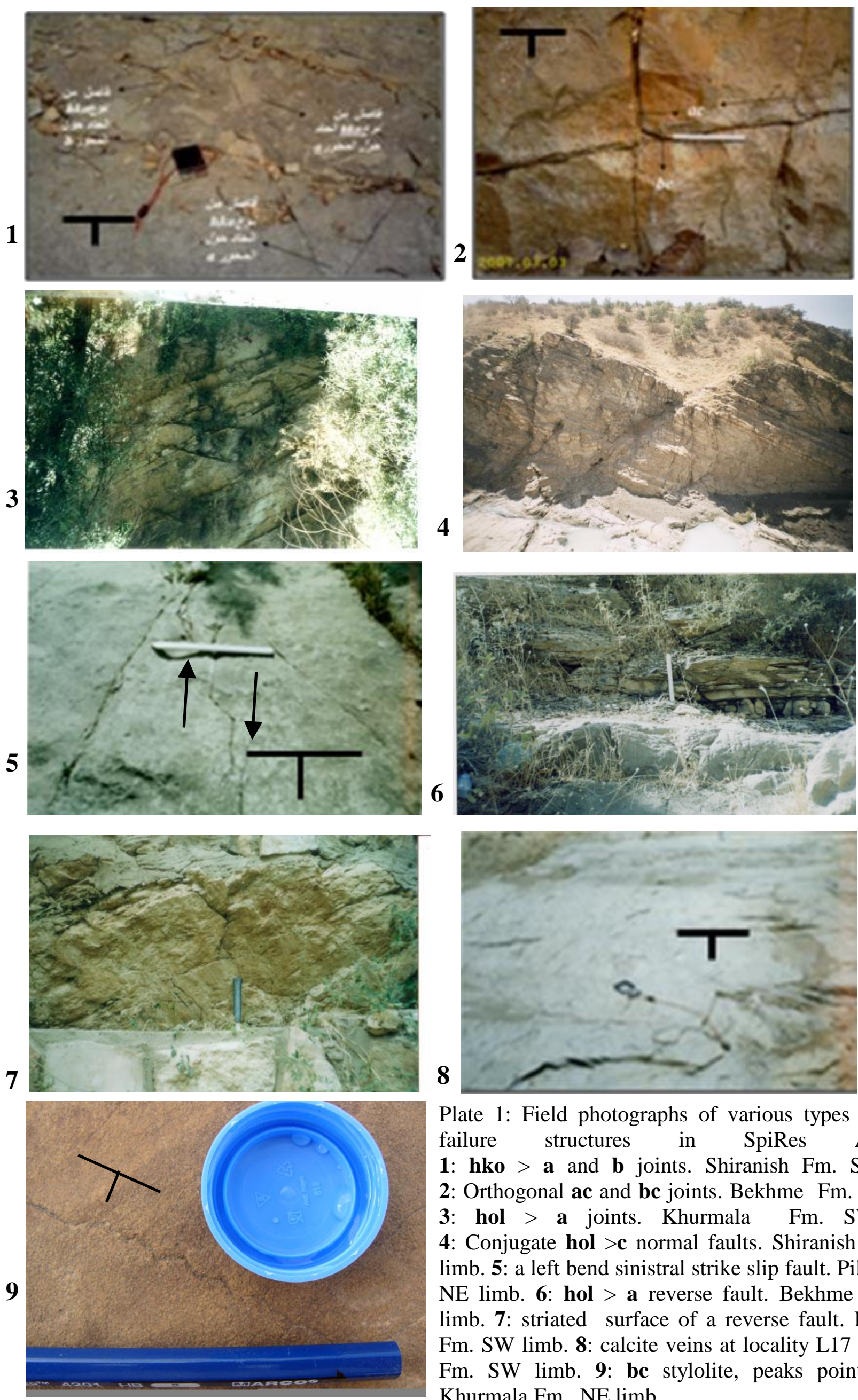

Plate 1: Field photographs of various types of brittle failure structures in SpiRes Anticline. 1: hko $>\mathbf{a}$ and b joints. Shiranish Fm. SW limb. 2: Orthogonal ac and bc joints. Bekhme Fm. NE limb. 3: hol $>$ a joints. Khurmala Fm. SW limb. 4: Conjugate hol $>$ c normal faults. Shiranish Fm. SW limb. 5: a left bend sinistral strike slip fault. PilaSpi Fm. NE limb. 6: hol $>$ a reverse fault. Bekhme Fm. SW limb. 7: striated surface of a reverse fault. Khurmala Fm. SW limb. 8: calcite veins at locality L17 Shiranish Fm. SW limb. 9: bc stylolite, peaks point a axis. Khurmala Fm. NE limb. 
Table 2: Attitudes, Sense of Slip and Ggeometrical Classes of Observed Faults in Spi Res Anticline.

\begin{tabular}{|c|c|c|c|c|c|}
\hline Location & Formation & $\begin{array}{c}\text { Attitude } \\
\text { Strike /dip }\end{array}$ & Pitch ( rake) & Slip sense & $\begin{array}{c}\text { Geometrical } \\
\text { class }\end{array}$ \\
\hline \multirow{3}{*}{ L1 } & \multirow{3}{*}{ PilaSpi } & $266 / 64$ & $70 \mathrm{SW}$ & reverse & okl $>b$ \\
\hline & & $263 / 64$ & $60 \mathrm{SW}$ & reverse & okl $>b$ \\
\hline & & $302 / 72$ & $70 \mathrm{NW}$ & reverse & hol>a \\
\hline L11 & Shiranish & $284 / 60$ & $84 \mathrm{SE}$ & reverse & hol>a \\
\hline L13 & PilaSpi & $168 / 60$ & $40 \mathrm{SE}$ & dextral & hko>a \\
\hline \multirow{6}{*}{ L16 } & \multirow{6}{*}{ Bekhme } & $322 / 60$ & $105 \mathrm{NW}$ & reverse & hol>a \\
\hline & & $122 / 36$ & $82 \mathrm{NW}$ & reverse & hol>a \\
\hline & & $272 / 50$ & $60 \mathrm{~W}$ & reverse & hol>a \\
\hline & & $260 / 52$ & $65 \mathrm{~W}$ & reverse & okl $>b$ \\
\hline & & $336 / 75$ & 90 & reverse & hol>a \\
\hline & & $332 / 68$ & 90 & reverse & hol $>a$ \\
\hline \multirow{2}{*}{ L17 } & \multirow{2}{*}{ Shiranish } & $324 / 60$ & $100 \mathrm{NW}$ & reverse & hol>a \\
\hline & & $342 / 80$ & 90 & reverse & hko>a \\
\hline \multirow{9}{*}{ L19 } & \multirow{9}{*}{ Khurmala } & $308 / 56$ & $160 \mathrm{NW}$ & sinistral & hol>a \\
\hline & & $008 / 48$ & $140 \mathrm{~N}$ & sinistral & okl $>b$ \\
\hline & & $356 / 58$ & $50 \mathrm{~N}$ & reverse- & okl $>b$ \\
\hline & & $316 / 40$ & $170 \mathrm{NW}$ & sinistral & hol>a \\
\hline & & 009 / 62 & $54 \mathrm{~N}$ & reverse & okl $>c$ \\
\hline & & $352 / 72$ & $68 \mathrm{~N}$ & reverse & okl $>c$ \\
\hline & & $356 / 76$ & $64 \mathrm{~N}$ & reverse & okl $>c$ \\
\hline & & $310 / 38$ & $42 \mathrm{NW}$ & reverse & hol $>a$ \\
\hline & & $354 / 48$ & $40 \mathrm{~N}$ & reverse & okl $>b$ \\
\hline L20 & Gercus & $006 / 88$ & $170 \mathrm{~N}$ & sinistral & hko>a \\
\hline \multirow{5}{*}{ L21 } & \multirow{5}{*}{ PilaSpi } & $206 / 87$ & $170 \mathrm{SW}$ & dextral & hko>a \\
\hline & & $312 / 86$ & $150 \mathrm{NW}$ & sinistral & hko >b \\
\hline & & $200 / 80$ & $144 \mathrm{SW}$ & dextral & hko>a \\
\hline & & $332 / 88$ & $145 \mathrm{NW}$ & sinistral & hko>a \\
\hline & & $330 / 80$ & $150 \mathrm{NW}$ & sinistral & hko>a \\
\hline \multirow{3}{*}{ L25 } & \multirow{3}{*}{ Shiranish } & $320 / 58$ & $80 \mathrm{NW}$ & reverse & hko $>b$ \\
\hline & & $014 / 38$ & $80 \mathrm{~N}$ & reverse & okl>b \\
\hline & & $340 / 72$ & 90 & reverse & hko>a \\
\hline
\end{tabular}




\section{VEINS}

Groups of planar veins found in various lithological units of study area (L1, L3, L7, L8, L9, L10, L11, L16, L17, L22), their thicknesses range from many millimeters to several centimeters. Geometrically they lie into same prevailing sets of joints (Photo 8). Their material consists mainly of their host rocks (i.e calcite crystal aggregates) and subordinately of silica. However, syntaxial fibrous veins with well developed median lines registered in locality (L1) in PilaSpi Limestone Fm.

The blocky crystalline pattern of most observed veins in study area refers that they have been developed closer to earth surface, where rock strength was sufficient to permit a cavity to stay open or fluid pressure was great enough to hold the fracture open. The previously formed vein fill, later recrystallized to form blocky crystals, or that there were few nucleation sites for crystals to grow from during vein formation (Van der Pluijm and Marshak, 2004).

The high density of veins in Garmawa valley exposures reflects the extra tectonic activity in this part of the structure. Particularly this valley delineate the trace of a dextral major strike slip fault interpreted from satellite imagery of the region (Al-Azzawi and Al-Hubiti, 2009). The characterized tectonic activity of this valley is presumed also from concentration of striated mesofault surfaces there.

\section{STYLOLITES}

They are saw like rock discontinuities showing alternating peaks and hollows. They are common in carbonate rocks and occasionally exist in siliceous rocks like sandstones. They form when the rock body subjected to compressive stress in presence of pressured solution. The cause of Peaks and hollows is the variance of dissolving rate due to inhomogeous distribution of impurities in the rock. They developed either along preexisting discontinuities or in intact rocks. There are two main types of stylolite; conical and cylindrical. The first is tectonic whereas the second is related to digenetic history of the rock. However, Stylolite seams normal and inclined to bedding are of tectonic origin. Whereas the origin of bedding parallel seams remains controversial, some attribute them to digenetic process following lithification of sediments, others relate them to layer parallel tectonic stretch where the maximum principal stress is vertical (Suppe, 1985; Ble`s and Feuga, 1986; Nicolas 1987; Sinha-Roy, 2002; Shadmon, 2008).

Most authors emphasize that stylolite seams can form perpendicular to the maximum principal stress $\boldsymbol{\delta}_{\mathbf{1}}$, where their peaks refer to this direction. Thus they commonly associated orthogonally with planar or en echelon vein arrays. However, when stylolites accompany faults then their peaks indicate slip directions of such faults (Fletcher and Pollard, 1981; Bucher, 1981 ; Mullenax and Gray, 1984; Hancock, 1985 ; Ble`s and Feuga, 1986 ; Nicolas, 1987; Van der Pluijm and Marshak, 2004). 
Stylolite occurrence is very little in study area compared to other types of brittle failure structurs. They are of conical type and their traces appear either on bedding surfaces or on lateral faces of beds (on joint faces) (Photo 9; Table 3).

In spite of their little occurrence, two sets of stylolite seams were recognized in rock units of SpiRes Anticline. One with peaks directed normal to fold hinge, whereas peaks of other set alongside the hinge. Thus, the first set expresses the primary compressive stress that formed the fold, whereas the second refers to subordinate compressive stress along fold hinge during relaxation of the primary compression.

Table 3: Geometrical Parameters of Llimited Stylolite Sets in SpiRes Anticline.

\begin{tabular}{|c|c|c|c|c|c|}
\hline $\begin{array}{l}\text { Location } \\
\text { Bedding }\end{array}$ & Formation & $\begin{array}{c}\text { Anticline } \\
\operatorname{limb}\end{array}$ & $\begin{array}{c}\text { Attitude of } \\
\text { joint } \\
\text { containing } \\
\text { stylolite trace }\end{array}$ & $\begin{array}{l}\text { Geometrical } \\
\text { class of joint }\end{array}$ & $\begin{array}{c}\text { direction of } \\
\text { stylolite } \\
\text { peaks }\end{array}$ \\
\hline $\begin{array}{c}\text { L2 } \\
278 \text { / } 52\end{array}$ & Avana & SW & 040 / 68 & hko>a & SW \\
\hline $\begin{array}{c}\text { L9 } \\
090 / 22\end{array}$ & Khurmala & $\mathrm{NE}$ & $090 / 20$ & Bedding & $\mathrm{NE}$ \\
\hline $\begin{array}{c}\text { L13 } \\
282 \text { / } 60\end{array}$ & Pila Spi & SW & $180 / 70$ & hko>a & SW \\
\hline $\begin{array}{c}\text { L19 } \\
305 \text { / } 28\end{array}$ & Khurmala & SW & $316 / 40$ & hol $>\mathrm{a}$ & NW \\
\hline L25 & Shiranish & SW & $301 / 72$ & hko $>b$ & NW \\
\hline
\end{tabular}

\section{PALEOSTRESS ANALYSIS}

The predominant hko joint systems both acute about $\mathbf{a}$ and $\mathbf{b}$ axes and striated mesofault surfaces were analyzed kinematically using TENSOR software of Delvaux ( Delvaux and Sperner, 2003) to extract paleostress principal axes acted in the investigated area during its deformational history. Strike slip paleostress states were obtained from analysis of hko shear joint systems as illustrated in (Tables, 4 and 5; Figs. 5, 6, 7, 8). The general directions of their maximum horizontal principal stress axes ( $\boldsymbol{\delta}_{\text {Hmax. }}$ ) fall in N-S, NE-SW, E-W and NW-SE. The first two orientations of $\left(\boldsymbol{\delta}_{\mathrm{Hmax}}\right)$ reflect the effect of both Taurus N-S and Zagros 
NE-SW tectonic compressive regimes. However the other two directions represent secondary compression of relaxation episodes of both Taurus and Zagros primary regimes respectively.

Furthermore, fault slip analysis of investigated area elucidated the following paleostress states according to directions of $\left(\boldsymbol{\delta}_{\mathrm{H} \max }\right)$ (Figure. 9):

1. ENE-WSW pure strike slip: deduced by dextral and senistral strike slip faults of hko acute about a system. Thus they may be of preexisting fractures formed in a previous N-S stress regime then have been reactivated as strike slip mesofaults in response to later stress regime (ENE-WSW).

2. NE-SW pure compressive : obtained by analysis of reverse slip faults in some localities of investigated area. The direction of $\boldsymbol{\delta}_{\mathbf{H} \max }$ of this tensor is comfortable with that extracted by hko acute about a shear joint system in locality (L16). It is obvious from (Figure 9) that six planes of this compressive stress state belong to hol acute about a system according to local bedding attitude at such locality. It seems that the stress regime responsible for activation of these six faults coincide with the stress regime that initiated the hol joints. Thus the initiation of these joints and their later on reactivation in a new stress regime coaxial with a previous one is probable. Meanwhile, the development of these planes as neoformed faults under the same stress regime is also possible. However two planes of this compressive state belong to hko acute about $\mathbf{b}$ system. This means that these planes were initiated as shear joints in a previous stress state then have been reactivated as reverse slip faults dueto this compressive stress state.

3. E-W pure compressive : derived by analysis of strike and reverse slip faults at locality (L19) (Fig. 9). The direction of $\boldsymbol{\delta}_{\mathbf{H} \max }$ of this tensor agree with that extracted from hko acute about $\mathbf{b}$ shear joints in localities (L2, L4, L5, L7, L10) (Table 5; Figs. 7, 8 ). The fault plane variations of this stress state in attitude, striation pitches and sense of slip (some strike slip and others reverse slip), outbalance the probability of initiation of these planes as joints under different stress states than the compressive stress state that had reactivated such joints as mesofaults.

4. NW-SE pure compressive : deduced by analysis of a group of reverse slip faults at locality (L1) (Fig. 9 ). The $\boldsymbol{\delta}_{\mathbf{H} \text { max }}$ of this stress tensor orientation is agree with those concluded by hko acute about $\mathbf{b}$ shear joints at the same locality.

It is obvious therefore, that $\boldsymbol{\delta}_{\text {Hmax }}$ of groups of mesofaults in Spi Res Anticline have general trend of NE-SW, E-W and NW-SE directions. They are in good agreement with those obtained from analysis of hko acute about $\mathbf{a}$ and $\mathbf{b}$ shear joints. 
Table 4 : Stress Tensors Extracted by Kinematic Analysis of hko>a Shear Joints in Spi Res Anticline. Comp. St.: Compressive Strike Slip; Ext. St.: Extensive Strike Sslip; Pure St.: Pure Strike Slip.

\begin{tabular}{|c|c|c|c|c|c|c|}
\hline \multirow{2}{*}{$\begin{array}{l}\text { Formation } \\
\text { locality }\end{array}$} & \multirow{2}{*}{$\begin{array}{l}\text { Bedding } \\
\text { attitude }\end{array}$} & \multicolumn{3}{|c|}{$\begin{array}{c}\text { Principal stresses attitudes } \\
\text { Azimuth/plunge }\end{array}$} & \multirow{2}{*}{$\begin{array}{c}\text { Stress } \\
\text { ratio } \\
\mathbf{R}\end{array}$} & \multirow{2}{*}{$\begin{array}{c}\text { Tensor } \\
\text { type }\end{array}$} \\
\hline & & $\delta 1$ & $\delta 2$ & $\delta 3$ & & \\
\hline $\begin{array}{c}\text { Avana } \\
\text { L3 }\end{array}$ & $288 / 50$ & $184 / 10$ & $016 / 80$ & $274 / 02$ & 0.57 & Pure St. \\
\hline $\begin{array}{l}\text { Pila Spi } \\
\text { L4 }\end{array}$ & $286 / 45$ & $189 / 22$ & $352 / 68$ & 096/04 & 0 & Comp.St. \\
\hline $\begin{array}{l}\text { Shiranish } \\
\text { L7 }\end{array}$ & $098 / 20$ & $004 / 22$ & $182 / 68$ & $274 / 01$ & 0.6 & Pure St. \\
\hline $\begin{array}{l}\text { Shiranish } \\
\text { L8 }\end{array}$ & $090 / 24$ & $003 / 25$ & $190 / 65$ & 094/03 & 0.75 & Ext. St. \\
\hline $\begin{array}{c}\text { Khurmala } \\
\text { L9 }\end{array}$ & $090 / 22$ & $005 / 33$ & $194 / 57$ & 098/04 & 0.48 & Pure St. \\
\hline $\begin{array}{l}\text { Khurmala } \\
\text { L14 }\end{array}$ & $288 / 50$ & $204 / 04$ & $092 / 80$ & $296 / 10$ & 0.5 & Pure St. \\
\hline $\begin{array}{l}\text { Bekhme } \\
\text { L16 }\end{array}$ & $314 / 18$ & $216 / 11$ & $050 / 78$ & $306 / 03$ & 0.9 & Ext. St. \\
\hline $\begin{array}{l}\text { Shiranish } \\
\text { L17 }\end{array}$ & $308 / 22$ & 037/06 & $148 / 74$ & $305 / 15$ & 0.83 & Ext. St. \\
\hline $\begin{array}{l}\text { Shiranish } \\
\text { L18 }\end{array}$ & $318 / 20$ & $226 / 16$ & $076 / 72$ & $318 / 09$ & 0.67 & Pure St. \\
\hline $\begin{array}{l}\text { Khurmala } \\
\text { L19 }\end{array}$ & $305 / 28$ & $228 / 16$ & $040 / 75$ & $136 / 02$ & 1 & Ext. St. \\
\hline
\end{tabular}



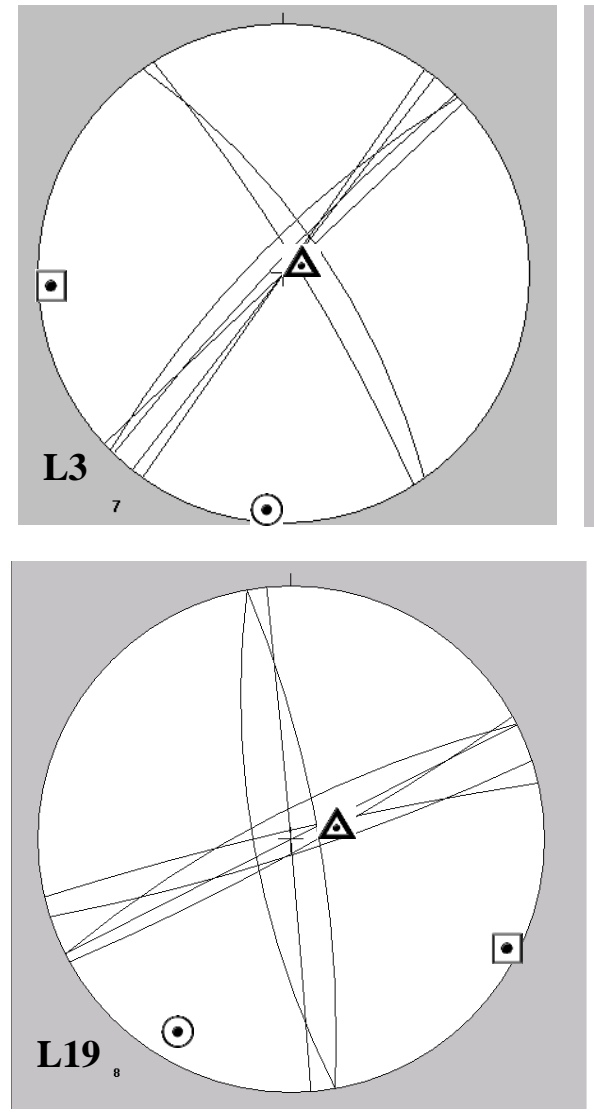
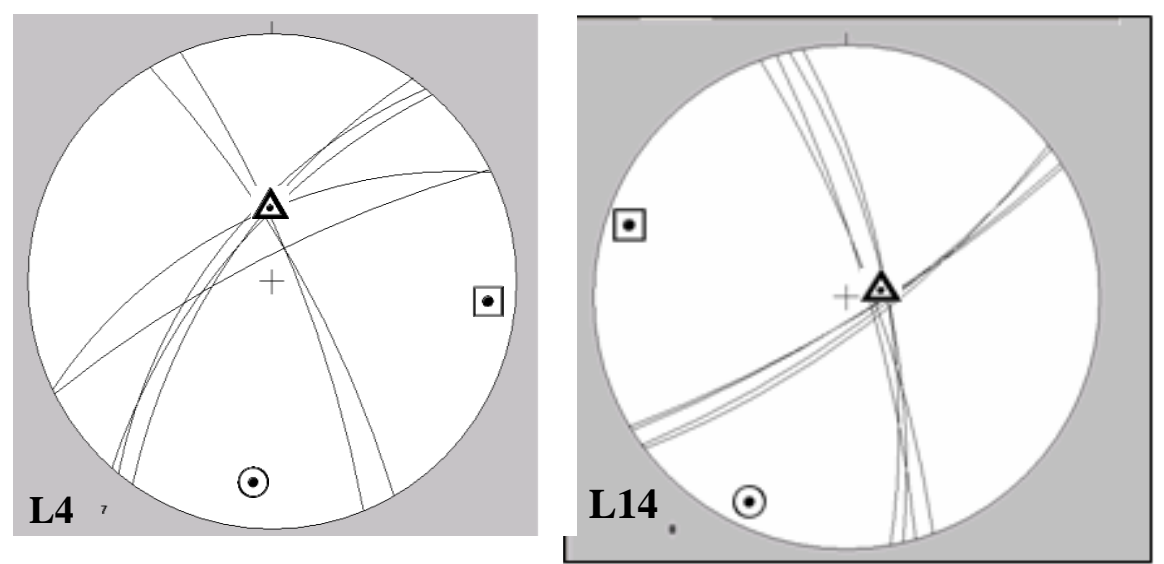

Fig. 5: Stereographic Representation of Available Complimentary hko>a Shear Joint Sets with their Computed Principal Stress Axes after Restoration of Bedding Dips of the Respective Localities to Horizontal: Maximum $\odot$ principal Stress $\left(\boldsymbol{\delta}_{\mathbf{1}}\right)$, Intermediat $\Delta$ principal Stress $\left(\boldsymbol{\delta}_{2}\right)$, : MinimunPrincipal Stress $\left(\boldsymbol{\delta}_{\mathbf{3}}\right)$. 

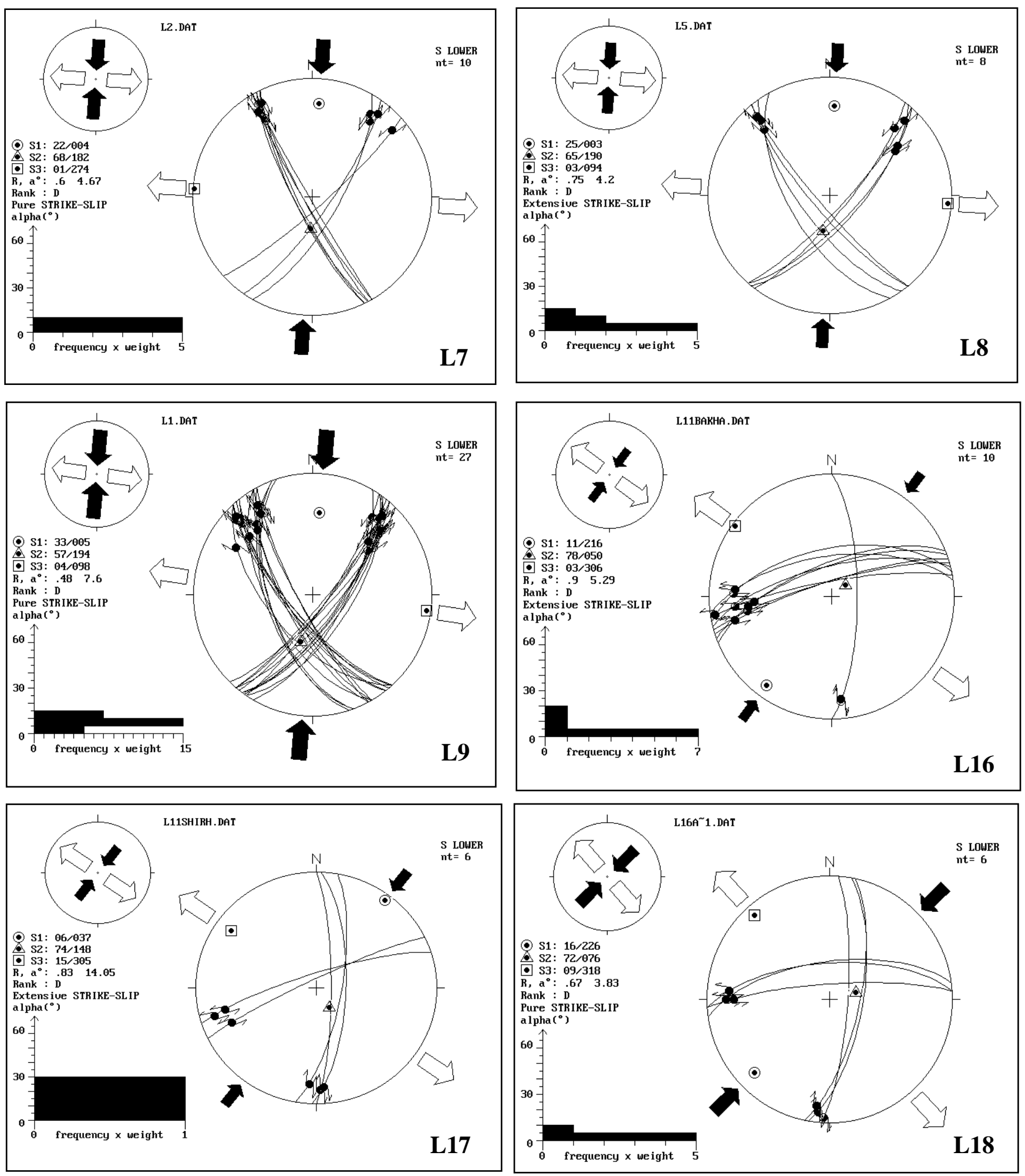

Fig. 6 : Stereographic Representations of Stress Tensors Computed from Available Complimentary hko>a Shear Joint Sets at Specified Localities in Spi Res Anticline. Principal Stress Symbols are as in Fig. 5. 
Table 5: Stress Tensors Extracted by Kinematic Analysis of hko>b Shear Joints in Spi Res Anticline. Comp. St.: Compressive Strike Slip; Ext. St.: Extensive Strike Slip; Pure St.: Pure Strike Slip.

\begin{tabular}{|c|c|c|c|c|c|c|}
\hline \multirow{2}{*}{$\begin{array}{c}\text { Formation } \\
\text { locality }\end{array}$} & \multirow{2}{*}{$\begin{array}{l}\text { Bedding } \\
\text { attitude }\end{array}$} & \multicolumn{3}{|c|}{$\begin{array}{c}\text { Principal stresses attitudes } \\
\text { Azimuth/plunge }\end{array}$} & \multirow{2}{*}{$\begin{array}{c}\text { Stress } \\
\text { ratio } \\
\mathbf{R}\end{array}$} & \multirow{2}{*}{ Tensor type } \\
\hline & & $\delta 1$ & $\delta 2$ & $\delta 3$ & & \\
\hline $\begin{array}{l}\text { Pila Spi } \\
\text { L1 }\end{array}$ & $290 / 48$ & $292 / 11$ & $112 / 78$ & 018/06 & 0.2 & Comp.St. \\
\hline $\begin{array}{c}\text { Avana } \\
\text { L2 }\end{array}$ & $278 / 52$ & $109 / 18$ & $258 / 62$ & $015 / 20$ & 1 & Ext. St. \\
\hline $\begin{array}{l}\text { Pila Spi } \\
\text { L4 }\end{array}$ & $286 / 45$ & $276 / 10$ & $126 / 78$ & 010/04 & 0.17 & Comp.St. \\
\hline $\begin{array}{l}\text { Bekhme } \\
\text { L5 }\end{array}$ & $092 / 38$ & $273 / 02$ & $179 / 65$ & $004 / 25$ & 0 & Comp.St \\
\hline $\begin{array}{l}\text { Shiranish } \\
\text { L7 }\end{array}$ & $098 / 20$ & $097 / 10$ & $210 / 66$ & $003 / 22$ & 0.43 & Pure St. \\
\hline $\begin{array}{c}\text { Khurmala } \\
\text { L9 }\end{array}$ & $090 / 22$ & $273 / 06$ & $168 / 68$ & $006 / 21$ & 0.5 & Pure St. \\
\hline $\begin{array}{l}\text { Shiranish } \\
\text { L10 }\end{array}$ & $290 / 40$ & $264 / 04$ & 082/88 & $172 / 02$ & 1 & Ext. St. \\
\hline $\begin{array}{l}\text { Shiranish } \\
\text { L11 }\end{array}$ & $288 / 32$ & $104 / 02$ & 018/86 & $020 / 02$ & 0 & Comp.St. \\
\hline $\begin{array}{c}\text { Avana } \\
\text { L12 }\end{array}$ & $278 / 52$ & $281 / 28$ & 087/60 & $188 / 04$ & 0.6 & Pure St. \\
\hline $\begin{array}{c}\text { Khurmala } \\
\text { L14 }\end{array}$ & $288 / 50$ & $292 / 14$ & $116 / 78$ & $020 / 02$ & 0.25 & Comp.St \\
\hline $\begin{array}{l}\text { Shiranish } \\
\text { L17 }\end{array}$ & $308 / 22$ & $134 / 03$ & $034 / 73$ & $225 / 17$ & 0.17 & Comp. St \\
\hline $\begin{array}{c}\text { Khurmala } \\
\text { L19 }\end{array}$ & $305 / 28$ & $310 / 07$ & $059 / 69$ & $217 / 20$ & 0.7 & Pure St. \\
\hline
\end{tabular}



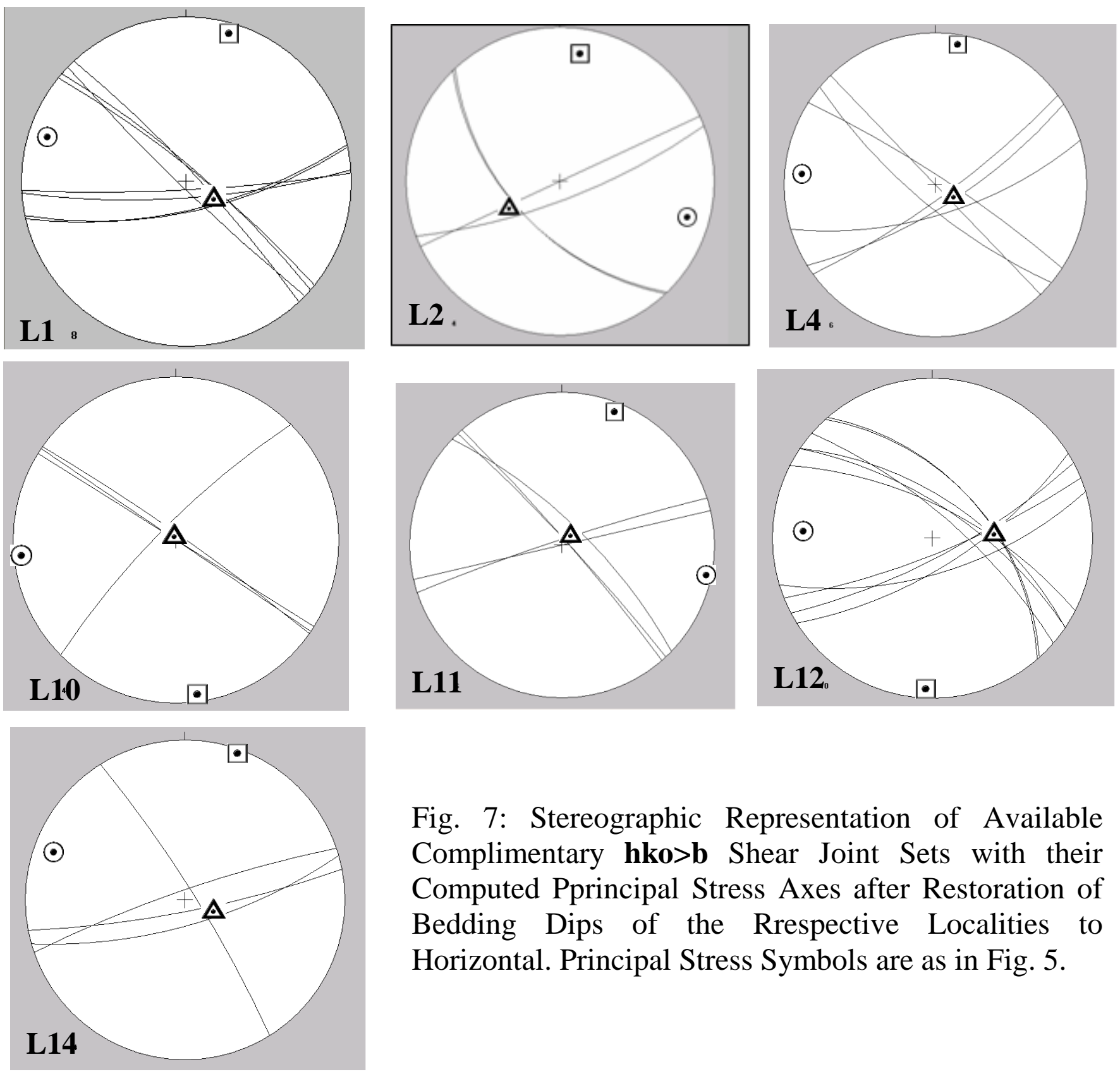

Fig. 7: Stereographic Representation of Available Complimentary hko>b Shear Joint Sets with their Computed Pprincipal Stress Axes after Restoration of Bedding Dips of the Rrespective Localities to Horizontal. Principal Stress Symbols are as in Fig. 5. 

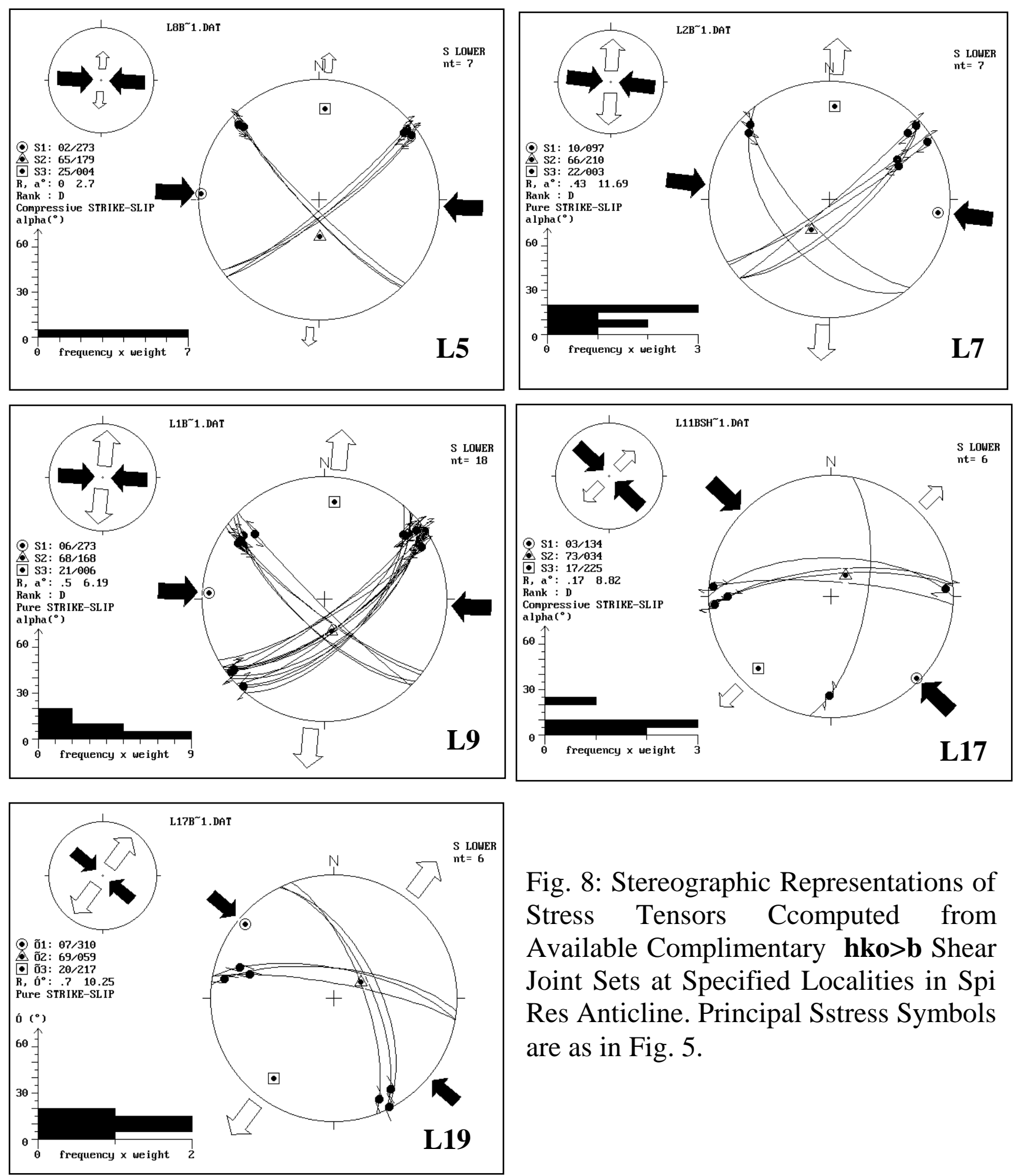

Fig. 8: Stereographic Representations of Stress Tensors Ccomputed from Available Complimentary hko>b Shear Joint Sets at Specified Localities in Spi Res Anticline. Principal Sstress Symbols are as in Fig. 5. 


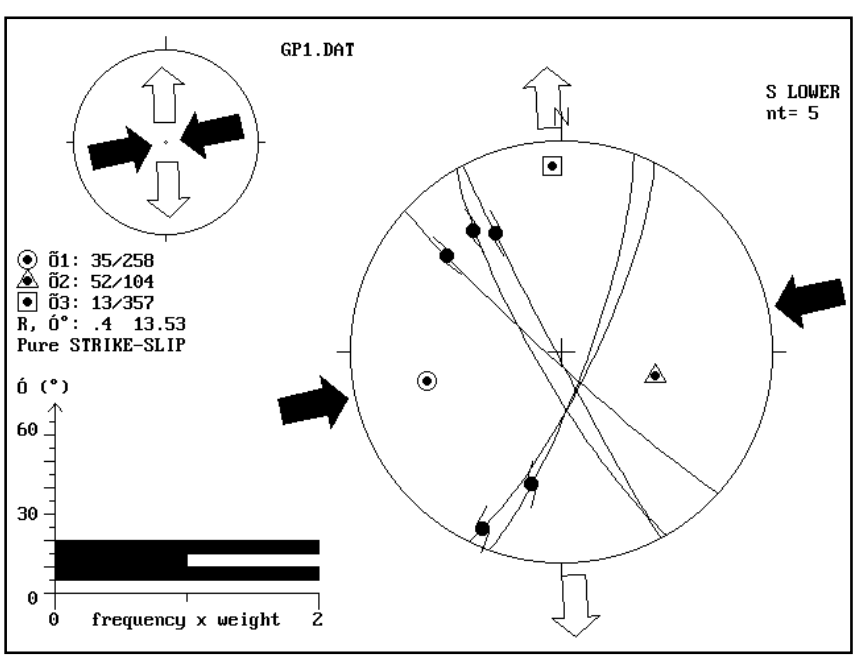

ENE-WSW Pure strike slip tensor L21, L22

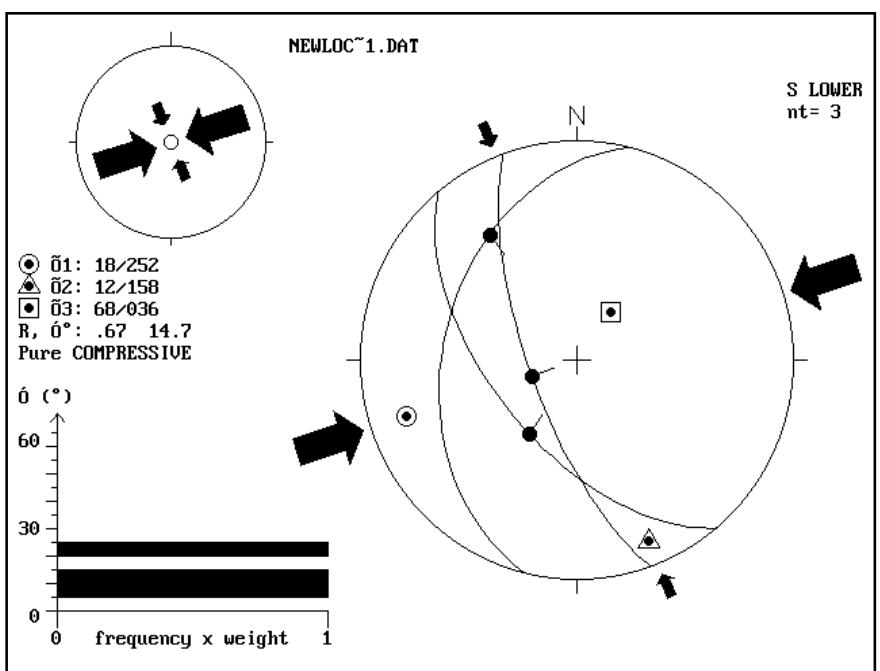

NE-SW Pure compressive tensor

L25

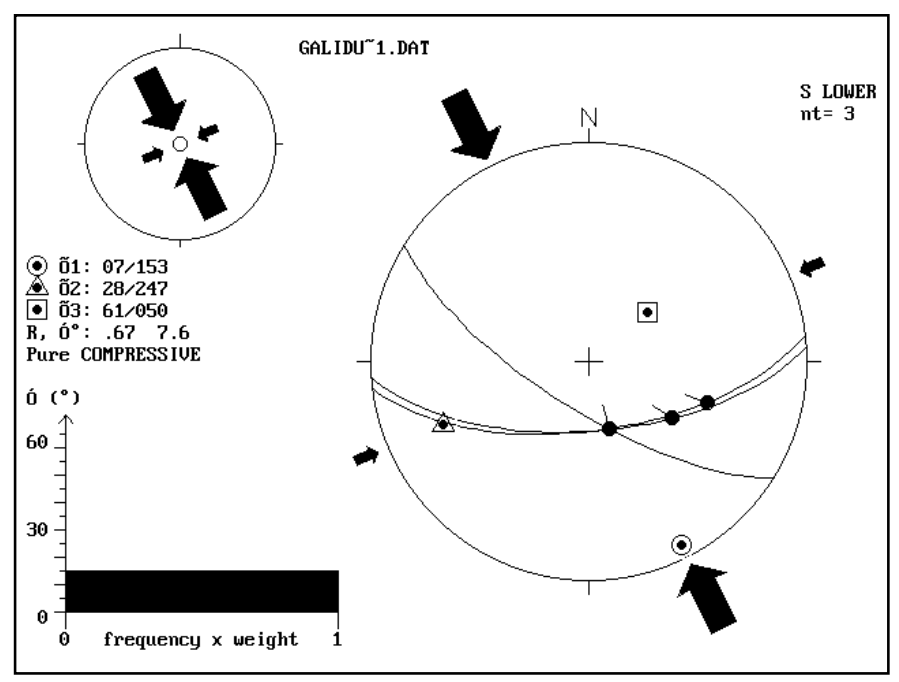

NW-SE Pure compressive tensor

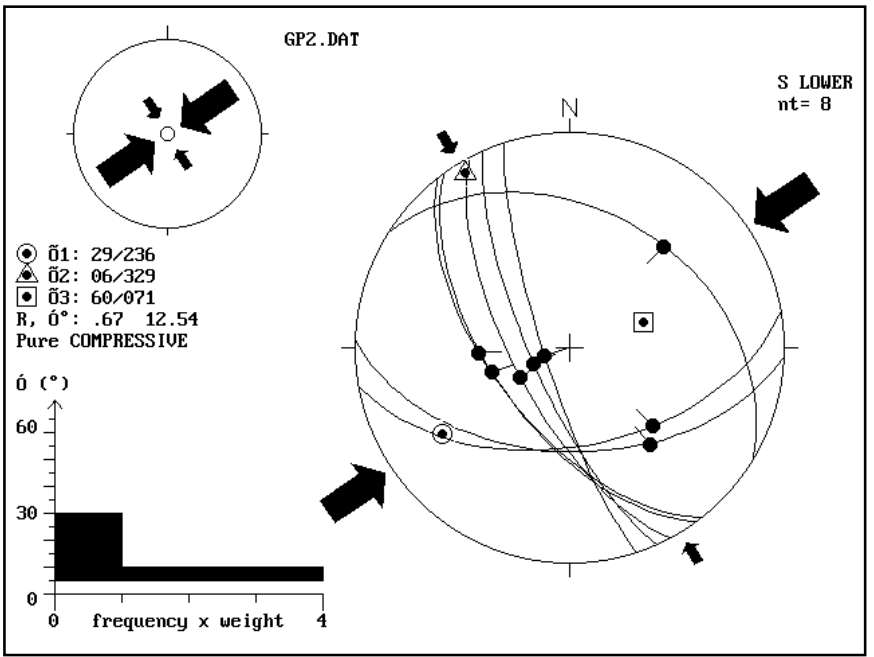

NE-SW Pure compressive tensor

L16

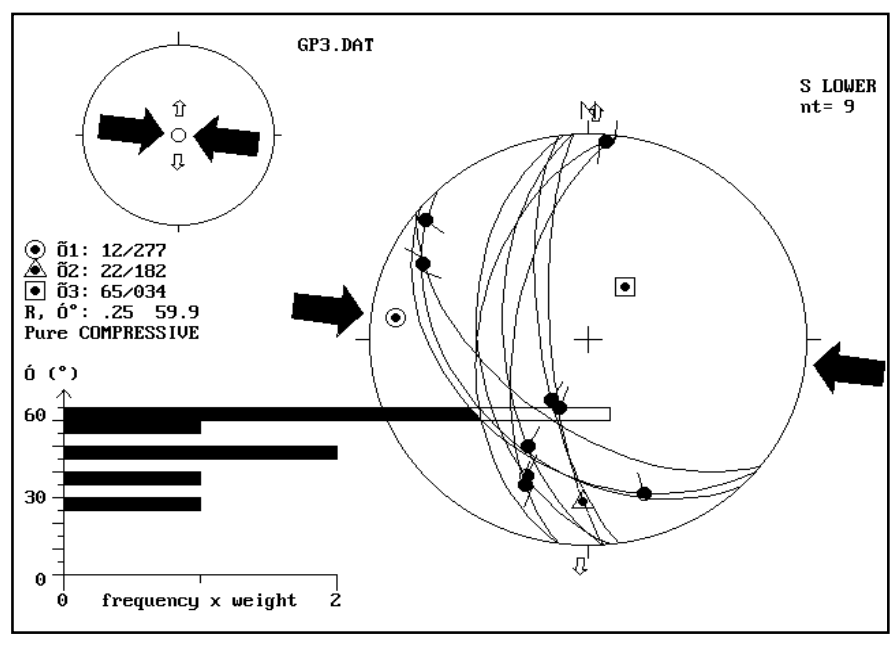

E-W Pure compressive tensor

$$
\text { L19 }
$$

Fig. 9: Stereographic Rrepresentation of Stress Tensors Extracted by Kinematic Analysis of Available Fault Slip Data at some Localities in Spi Res Anticline. Principal Stress Symbols are as in Fig. 5. 


\section{KINEMATIC RELATIONSHIP OF JOINTS, MESOFAULTS WITH MAJOR FAULTS}

Kinematic correlation between major and minor faults and with their associated shear joints is a useful test for considering whether these structures are compatible or not. If the analyzed stress regime from joints and minor faults accommodated with the movement sense of major faults, then such major and minor structures are said to be compatible and might be attributed to the same tectonic phase. Thus the major and minor structures might be contemporaneous. Otherwise, if the relationship is incompatible, then the major and minor structures might ought to different stress regimes in direction and time (i.e different tectonic phases), or the preexisting major ones cause perturbation of regional stress field within their vicinities. So local stresses might rise and secondary faults and fractures could develop close to major ones. (Hobbs et al., 1976; Suppe, 1985; Ble`s and Feuga, 1986; Ramsay and Huber, 1987; Twiss and Moores, 2007).

Comparison of paleostress tensors deduced from kinematic analysis of widespread hko shear joints and minor faults with the slip senses of major faults interpreted from Google earth imagery (Al-Azzawi and Al-Hubiti, 2009), and projecting them on to the geologic map of Spi Res Anticline show that (Fig. 10):

1. $\boldsymbol{\delta}_{\mathbf{H m a x}}$ of the most stress tensors of hko acute about a shear joints is compatible with the slip vector of Garmawa valley dextral strike slip major fault.

2. $\boldsymbol{\delta}_{\text {Hmax }}$ of the most stress tensors of hko acute about $\mathbf{b}$ shear joints particularly of E-W direction is compatible with the slip vector of dextral strike slip major fault transverse to fold hinge at SE plunge of Spi Res Anticline. However the NW-SE direction is incompatible with the movement sense of this major fault. Such this inconsistency might be related to perturbation of regional stress field a round the major fault.

3. $\boldsymbol{\delta}_{\mathrm{Hmax}}$ of some stress tensors detected from minor faults particularly those of NESW direction agree with the slip vector of Garmawa valley dextral strike slip major fault.

4. NW-SE $\boldsymbol{\delta}_{\text {Hmax }}$ obtained from minor faults seems incompatible with the slip vector of the dextral strike slip major fault transverse to fold hinge at SE plunge of Spi Res Anticline. This incompatibility might be attributed to perturbation of regional stress field caused by slip of this major fault during development of such nearby minor faults.

5. E-W $\boldsymbol{\delta}_{\text {Hmax }}$ deducted from minor strike slip faults at localities (L21, L22) is compatible with the slip vector of dextral strike slip major fault transverse to fold hinge at SE plunge of Spi Res Anticline.

Therefore, it is concluded that the slip sense of Garmawa major strike slip fault might be attributed to the primary compressive stress regime directed N-S or NE$\mathrm{SW}$. The movement of this major fault might had reactivated local fractures and 
joints in Garmawa valley as minor faults. However slip sense of the other major strike slip fault (near the SE plunge of SpiRes Anticline) might belongs to the relaxation stress succeeding the primary compressive regime when $\boldsymbol{\delta}_{\mathbf{H m a x}}$ directed $\mathrm{E}-\mathrm{W}$ in general.

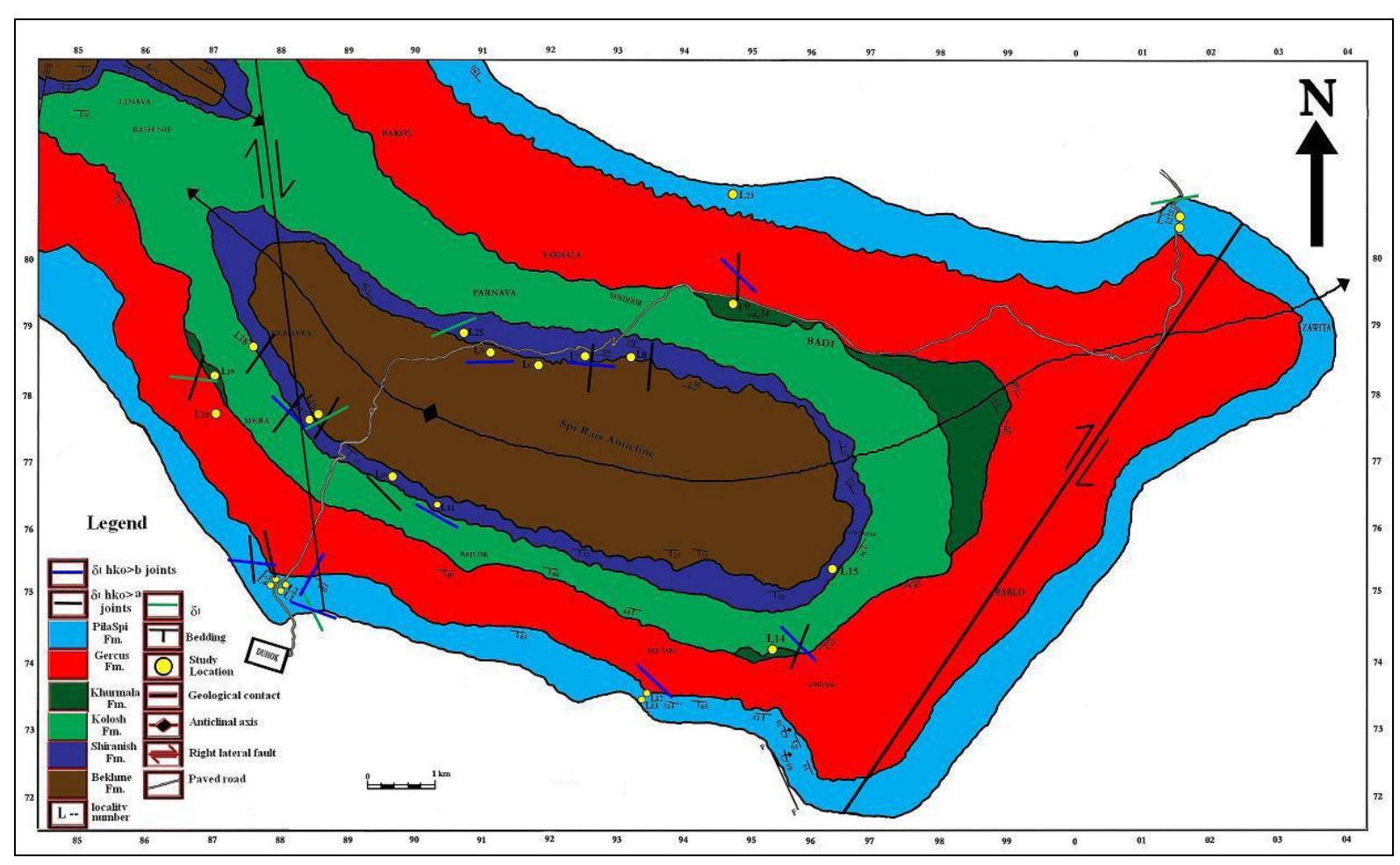

Fig. 10: Paleostress Trajectory Map of Spi Res Anticline. Horizontal Projection of Maximum Principal Stress Aaxis $\boldsymbol{\delta}_{\mathbf{1}}$ as Extracted from Kinematic Analysis of hko>a and b Shear Joints and Mesoscopic Ffaults. Traces of Major Faults Interpreted from Google Earth Imagery (Al-Azzawi and Al-Hubiti, 2009). Geologic Map is after (Al- Alawi, 1980).

\section{CORRELATION OF BRITTLE FAILURE STRUCTURES BETWEEN CRETACEONS AND TERTIARY ROCKS IN THE STUDY AREA}

Numan $(2000 ; 2001 \mathrm{a})$ emphasized two phases of Zagros orogeney in northern Iraq at ends of Cretaceous and Tertiary ages. The first one marks the dynamic inversion of tectonic habitat in the region from extension to compression. Whereas the later one had built up the present structural grain of the region after oblique collision of Arabia against Eurasia (Agard et al., 2005; Numan, 1997). Furthermore, Numan and Al-Azzawi $(1993 ; 2002)$ described shapes of folds that 
could have been initiated in Cretaceous rocks in the foreland fold belt of northern Iraq due to the first phase of such orogeny.

Therefore the present work focused to elucidate the impact of the Cretaceous end orogenic phase in initiation and evolution of brittle failure structures in rocks of this age in study area. This was done by comparison of following aspects of these structures between Cretaceous and Tertiary successions in study area :

\section{MODIFIED FRACTURES}

It is well known that the tectonic stress regime due to any orogenic phase can introduce new fractures as well as reactivate and modify preexisting fractures of a previous phase to more advanced styles ( Hancock, 1985; Ble`s and Feuga, 1986; Nicolas, 1987; Ramsay and Huber, 1987; Van der Pliujm and Marshak, 2004; Georg Mandl, 2005; Twiss and Moores, 2007).

Thus in study area, if Cretaceous rocks were containing fractures attributed to the end Cretaceous orogenic phase, then such fractures would have been reactivated in the end of later Tertiary orogenic phase, and progressed into advanced types of brittle structures ( like striated faults, stylolites, en-echelon vein arrays). However same groups and types of striated mesofaults found in both Cretaceous and Tertiary successions in study area. Little stylolite seams observed only in three localities of both Cretaceous and Tertiary rock units. The vein arrays in study area are exclusively tabular and existing in both rock units. Therefore, it is unlike to say that the Cretaceous end orogenic phase had imprinted brittle deformation structures into rocks of this age in study area. That is the present brittle failure structures in both Cretaceous and Tertiary successions of study area are exclusively the product of Tertiary end orogenic phase.

\section{JOINT DISTRIBTION}

A statistical comparison of joints between Cretaceous and Tertiary units in this study revealed (Table 6):

1. Same prevailing joint sets and systems were registered in rock units of both ages in study area (Fig. 11).

2. A close percentage of the prevailing hko>a joint system between rock units of both ages.

3. A relative increase in percentage of the prevailing hko>b joint system in Cretaceous rocks. This might be attributed to the concentration of joint measurements at NW plunge nose of the anticline where good road cut exposures of Cretaceous age rocks are available. It is worth to mention that plunge noses of folds are domains of concentrated local stress field feasible for the formation of such these joints.

4. A marked increase of hol>a joints in Tertiary rocks. These are shear fractures related to limb deformation (Ble`s and Feuga, 1986) which prevail within 
steeper limbs of folds. Hence their presence concentrated in steeper layers of Pila Spi limestone Fm. at SW limb of the anticline, whereas few of these observed in moderately dipping cretaceous rocks on both limbs of the same anticline.

5. A relatively high percentages of $\mathbf{h o l}>\mathbf{c}$ and $\mathbf{o k l}>\mathbf{c}$ joints in Tertiary rocks. This is because these joints are extensional shear fractures develop within outer arcs of folded multilayer where there transversal and longitudinal tensional stresses concentrated. Thus they have been concentrated in Tertiary rock layers particularly in Pila Spi limestone Fm. which constitutes the outer arc of Spi Res Anticline.

6. A relative increase of $\mathbf{o k l}>\mathbf{b}$ joints in Tertiary rocks. This is because these joints belong to the relaxation period of the fold, where the local stress field reoriented so that $\boldsymbol{\delta}_{\mathbf{3}}$ and $\boldsymbol{\delta}_{\mathbf{1}}$ being respectively perpendicular and parallel to fold axis. Hence relaxation concentrates within outer arcs of folds, thus these joints appear with relatively high percentage in Tertiary rock layers which constitute the outer arc of Spi Res Anticline in this respect.

7. The relatively high percentage of tensional ac joints in Tertiary rocks is due to concentration of local tensional stresses parallel with fold axis in the outer arc of Spi Res Anticline. While, reduced percentage of released bc joints in Tertiary relative to Cretaceous rocks is related to measurement deficiency in the hinge zone of the fold, a favorable area for development of such release joints, where release tensional stresses concentrated. This zone is out of access due to erosion or topographically is very high.

Thus, there is no remarkable increase in joint sets nor their individual numbers in Cretaceous relative to Tertiary rocks in Spi Res Anticline. Therefore, it is reasonable to state according to present investigation, that joints found in Cretaceous and Tertiary rocks of study area may exclusively belong to the Tertiary end orogenic phase. 
Table 6: Numbers and Percentages of Various Joint Sets in Cretaceous and Tertiary Rocks in Spi Res Anticline

\begin{tabular}{|c|c|c|c|c|c|c|c|c|c|c|}
\hline $\begin{array}{r}\text { Number } \\
\text { Percentage }\end{array}$ & ac & bc & hko>a & hko >b & $\begin{array}{c}\text { hol> } \\
\mathbf{a}\end{array}$ & hol $>$ c & $\mathbf{o k l}>\mathbf{b}$ & okl $>\mathbf{c}$ & $\begin{array}{c}\text { Total } \\
\text { number }\end{array}$ & $\begin{array}{c}\text { Total } \\
\%\end{array}$ \\
\hline $\begin{array}{r}\text { Number of } \\
\text { Cretaceous locations }\end{array}$ & 9 & 6 & 11 & 11 & 1 & 4 & 2 & 5 & & \\
\hline $\begin{array}{r}\text { Number of Tertiary } \\
\text { locations }\end{array}$ & 12 & 7 & 12 & 12 & 2 & 8 & 5 & 10 & & \\
\hline $\begin{array}{r}\text { Number of } \\
\text { Cretaceous joints }\end{array}$ & $\begin{array}{c}12 \\
0\end{array}$ & 31 & 455 & 398 & 3 & 46 & 14 & 56 & 1123 & 50.86 \\
\hline $\begin{array}{r}\text { Number of Tertiary } \\
\text { joints }\end{array}$ & $\begin{array}{c}14 \\
7\end{array}$ & 25 & 445 & 304 & 6 & 54 & 17 & 87 & 1085 & 49.14 \\
\hline Total joint number & $\begin{array}{c}26 \\
7\end{array}$ & 56 & 900 & 702 & 9 & 100 & 31 & 143 & 2208 & \\
\hline $\begin{array}{r}\% \text { of Cretaceous } \\
\text { joints }\end{array}$ & $\begin{array}{l}44 . \\
94\end{array}$ & $\begin{array}{l}55 . \\
36\end{array}$ & 50.56 & 56.7 & 33.3 & 46 & 45.16 & 39.16 & & \\
\hline$\%$ of Tertiary joints & $\begin{array}{l}55 . \\
06\end{array}$ & $\begin{array}{r}44 . \\
64\end{array}$ & 49.44 & 43.3 & 66.7 & 54 & 54.84 & 60.84 & & \\
\hline
\end{tabular}




\begin{tabular}{|c|c|c|c|c|c|}
\hline Successio & \multicolumn{2}{|c|}{ Cretaceous } & \multicolumn{3}{|c|}{ Tertiary } \\
\hline Formation & Bekhme & Shiranish & Khurmala & Avana & PilaSpi \\
\hline NE limb & & & & & \\
\hline SW limb & & & & & \\
\hline
\end{tabular}

Fig. 11: Correlation Chart (Joint Pole Stereograms) Illustrating the same Occurrence of Joint Sets and Systems in both Cretaceous and Tertiary Rock Units of Study Area.

\section{DIHEDRAL ANGLES OF SHEAR JOINT SYSTEMS}

Stress magnitude difference $\left(\boldsymbol{\delta}_{\mathbf{1}^{-}} \boldsymbol{\delta}_{3}\right)$, angle of internal friction of rocks and pore pressure during fracturing seem to be significant factors controlling the amount of dihedral angles between the two complementary joint sets of any shear system. Stress difference in turn depends on tectonic stress intensity and lithostatic pressure (rock overburden load above fracturing zone) (Suppe, 1985 ; Hancock, 1985; Van der Pliujm and Marshak, 2004; Twiss and Moores, 2007). Typically the average dihedral angle between conjugate shear fractures in uniaxial compressive tests for carbonate rock samples approaches $\left(60^{\circ}\right)$. The average amount of this angle increases with increasing confining pressure ( lithostatic pressure in nature).

Considering the effect of lithostatic pressure (assuming constant impact of other factors), it is reasonable to expect enlargement of the dihedral angle between conjugate shear joints with depth from earth surface during fracturing (Hancock, 1985; Suppe, 1985,). Accordingly, amounts of dihedral angles between hko acute about $\mathbf{a}$ and $\mathbf{b}$ shear joints in study area must cluster into moderate and high angles in Cretaceous rocks if these rocks have been subjected to two episodes of brittle fracturing; firstly due to end Cretaceous orogenic phase (low lithostatic pressure, moderate dihedral angles), and secondly due to end Tertiary orogenic phase 
(high lithostatic pressure due to load of Tertiary rock units, high dihedral angles). However as evident from (Figs. 12-15 ) the amounts of these angles of both shear joint systems range from moderate to high in both rock units in study area. This doesn't assures the possibility of subjection of Cretaceous rocks to two episodes of fracturing.

\section{PALEOSTESS STATES}

A rock unit subjected to more than an orogenic phase in its deformational history reveals more paleostress states than if it had subjected to single phase. (Table 7) summarizes paleostress states obtained from hko acute about $\mathbf{a}$ and $\mathbf{b}$ shear joints systems in Cretaceous and Tertiary successions of study area. According to general trend of $\boldsymbol{\delta}_{\text {Hmax }}$, four main strike slip stress states recognized in either of Cretaceous and Tertiary successions. Moreover, taking stress ratio into account, the stress states rise up to eight and nine subordinate states in Cretaceous and Tertiary successions respectively.

Furthermore, paleostress states deduced from fault slip analysis, are greater in Tertiary than in Cretaceous rocks in study area (Fig. 9). Therefore, it is evident that the number of the main and subordinate stress states is either equivalent in both successions or it is relatively more in Tertiary than in Cretaceous rocks. Also there is no any considerable variation in $\boldsymbol{\delta}_{\mathrm{Hmax}}$ directions of such stress states between these successions. Nor there is systematic variation in stress ratio of the same stress state between rocks of these two ages. This again contradicts two episodes of brittle deformation in Cretaceous succession of study area.

Table 7: Main and Subordinate Paleostress Tensors as Deduced by hko>a and b

Shear Joints and Mesoscopic Faults in Spi Res Anticline.

\begin{tabular}{|c|c|c|c|c|c|c|c|c|c|c|c|c|c|}
\hline \multirow{2}{*}{ 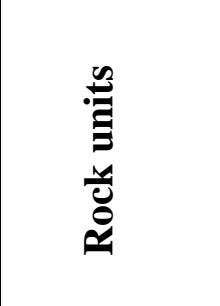 } & $\boldsymbol{\delta}_{\text {Hmax }}$ & \multicolumn{3}{|c|}{ N-S } & \multicolumn{3}{|c|}{ NE-SW } & \multicolumn{3}{|c|}{ E-W } & \multicolumn{3}{|c|}{ NW-SE } \\
\hline & $\begin{array}{l}\text { Tensor } \\
\text { (R) }\end{array}$ & C.S & P.S & E.S & C.S & P.S & E.S & C.s & P.S & E.S & C.S & P.S & E.S \\
\hline Cretaceous & $\sum 8$ & - & L7 & L8 & - & L18 & $\begin{array}{l}\text { L17 } \\
\text { L16 }\end{array}$ & \begin{tabular}{|l} 
L5 \\
L11
\end{tabular} & L7 & L10 & L17 & - & - \\
\hline Tertiary & $\sum 9$ & L14 & $\begin{array}{l}\text { L3 } \\
\text { L9 }\end{array}$ & - & - & L14 & L19 & $\begin{array}{l}\text { L4 } \\
\text { L1 }\end{array}$ & L12 & L2 & L14 & L19 & - \\
\hline Total $\sum$ & 10 & & & & & & & & & & & & \\
\hline
\end{tabular}




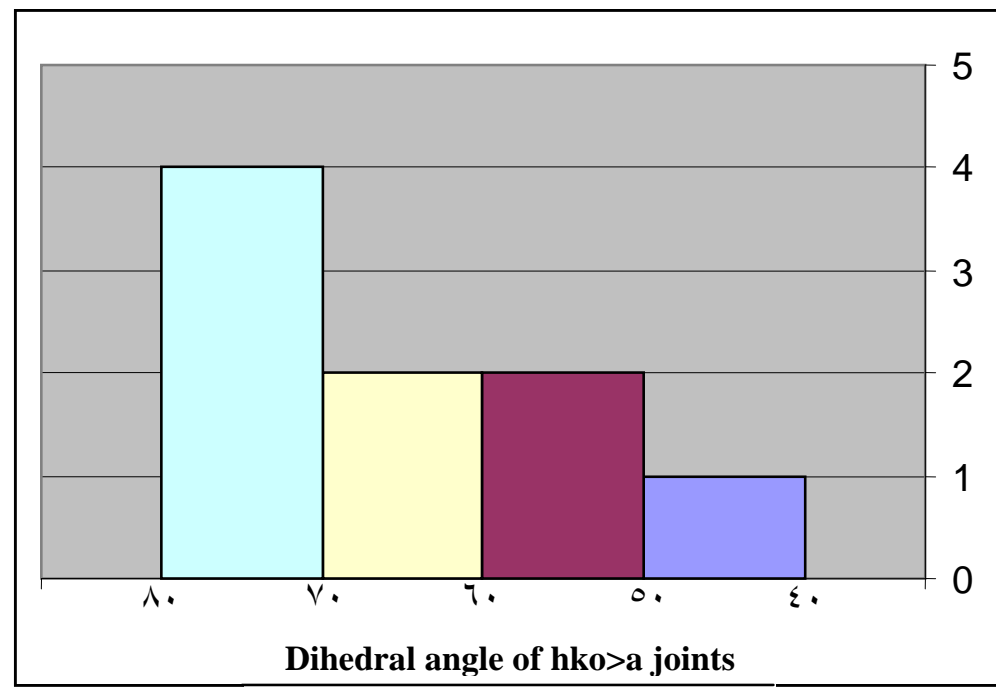

пко>a

Fig. 12 : Histogram of Dihedral Angle between the Complimentary Joint Sets of hko>a Svstem in Cretaceous Rocks of Spi Res Anticline

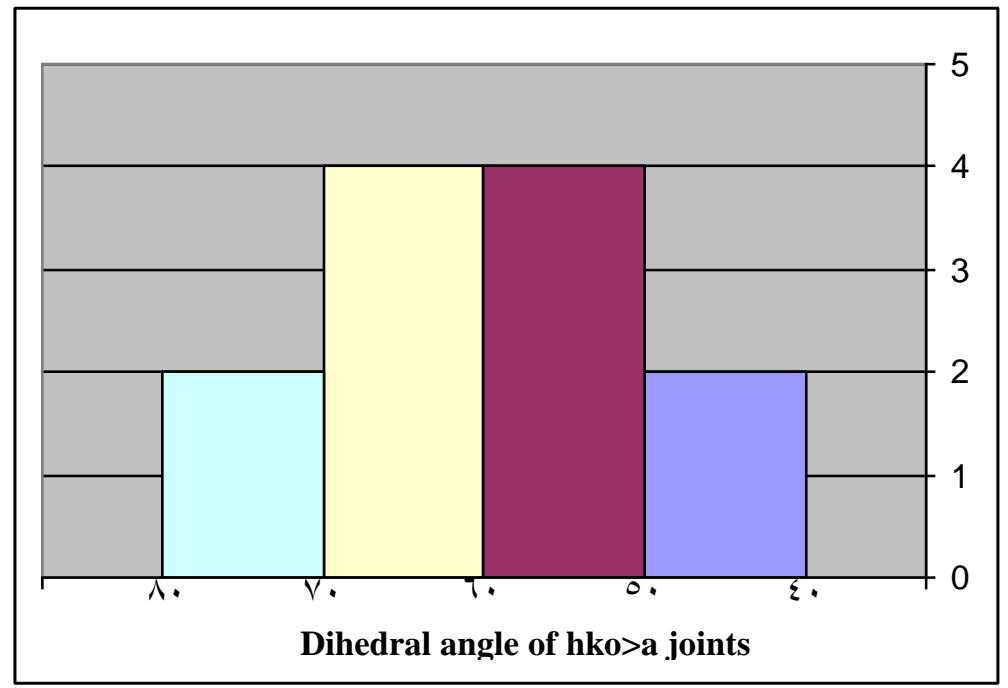

number of locations hko>a

Fig. 13 : Histogram of Dihedral Angle between the Complimentary Joint Sets of hko>a System in Tertiary Rocks of Spi Res Anticline.

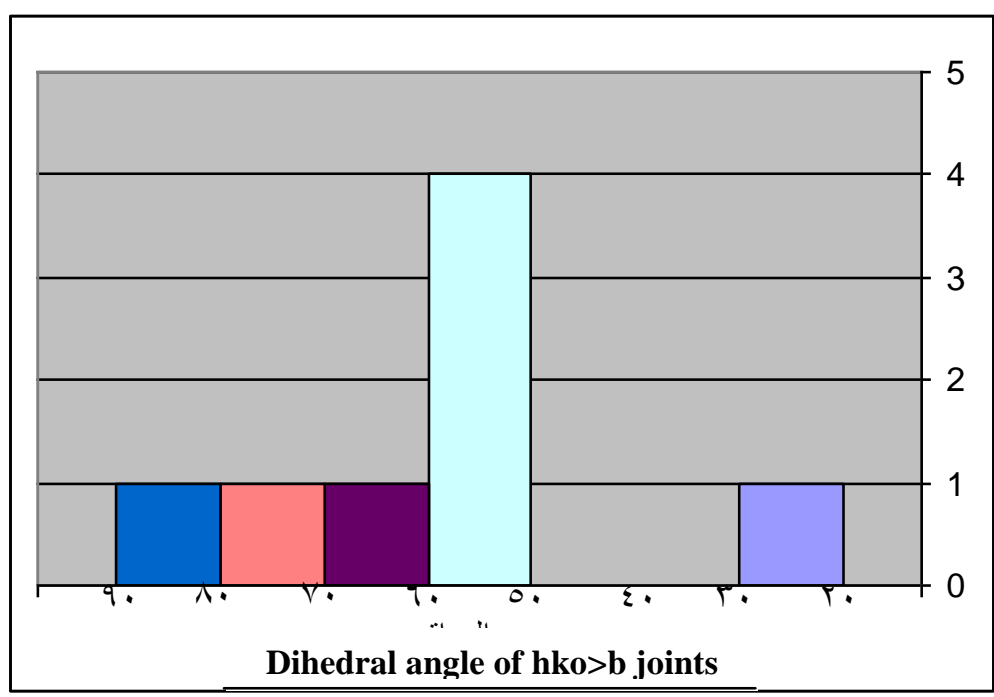

number of locations hko $>$ b

Fig. 14 : Histogram of Dihedral Angle between the Complimentary Joint Sets of hko>b System in Cretaceous Rocks of Spi Res Anticline. 


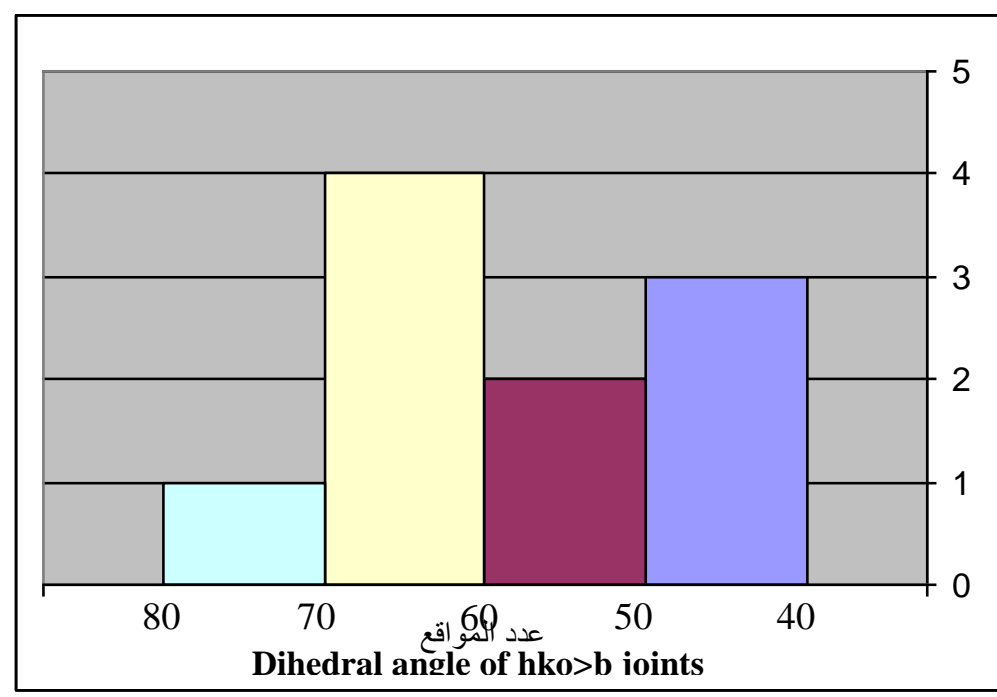

number of locations hko>b

Fig. 15 : Histogram of Dihedral Angle between the Complimentary Joint Sets of hko>b System in Tertiary Rocks of Spi Res Anticline.

\section{CONCLUSIONS}

1. The prevailing joints in study area are hko acute about $\mathbf{a}$ and $\mathbf{b}$ shear systems, then orthogonal $\mathbf{a c}$ and $\mathbf{b c}$ tension sets. They were formed under two regional stress regimes, one normal to Spi Res Anticline hinge, whereas the other is parallel to that hinge. However, other less prevailed systems are hol and okl systems, might have been formed under local stress regimes accompanying folding process.

2. No constant relative chronology among different joint sets and systems had been achieved in present work according to crosscutting and termination relationships. This may indicate that jointing had been accomplished through cycled and frequent pulses.

3. Both Cretaceous and Tertiary rock successions of Spi Res Anticline contain striated minor faults classified into reverse, normal and strike slip according to orientations of their surface striations with respect to their attitudes.

4. Groups of planar veins widespread in both Cretaceous and Tertiary rock units of study area. Most of them are of secondary origin, that they occupy cavities of opened joints. However, a few of them are kinematically significant.

5. Pressure solution structures (stylolite seams) are very scarce because the study area is relatively distant from orogenic front. The available sets refer to two 
directions of tectonic compression, one is primitive normal to fold axis, other is secondary and parallel with such axis.

6. Predominant stress states deduced from widespread shear joints are strike slip, whereas others deciphered from minor faults represent strike slip and compressive states as well.

7. According to directions of $\boldsymbol{\delta}_{\mathrm{Hmax}}$, the concluded paleostress states were categorized into two tectonic compressive directions of end Tertiary phase. one is in N-S or NE-SW ( normal to fold axis ), other is in E-W or NW-SE (parallel with fold axis).

8. No increase in types and numbers of brittle failure structures and stress states derived from them or in solid angles of conjugate shear joints, were detected in Cretaceous rock unit compared with Tertiary unit of study area. The interpretation is such that; the Cretaceous rocks might had not been underwent brittle deformation when subjected to the end Cretaceous orogeny phase, because of its probable inadequate solidity at that time. Their existent brittle structures like those of Tertiary rock unit belong to end Tertiary orogenic phase.

\section{REFERENCES}

Agard, P., Omrani, J., Jolivet, J., and Mouthereau, F., 2005. Convergence History Across Zagros (Iran): Constraints from Collisional and Earlier Deformation: International Journal of Earth Sciences, Vol. 94, pp. $401-419$.

Al-Azzawi, N. K. and Al-Hubiti, S. T., 2009. The Fold Style Variations of Baikher Anticline-Northern Iraq. Iraqi Jour. Earth Sci., Vol. 9, No. 1, pp. 1 - 20

Angelier, J., 1994. Fault Slip Analysis and Paleostress Reconstruction. In: Continental Deformation. Ed. P Hancock, Pergamon Oxford, pp. 53 - 100.

Ble`s, J. L. and Feuga, B., 1986. The Fracture of Rocks. North Oxford Academic Publishers Ltd., 131p.

Bucher, F., 1981. Rhine Graben: Horizontal Stylolites Indicating Stress Regimes of Earlier States of Rifting. Tectonophysics, Vol. 73, pp. 113 - 118.

Delvaux, D. and Sperner, B., 2003. Stress Tensor Inversion from Fault Kinematic Indicators and Focal Mechanism Data. The TENSOR Program. In: New Insights into Structural Interpretation and Modeling (D. Nieuwland Ed.); Geol. Soc. London, Special Publications, Vol. 212, pp. 75 - 100.

Fletcher, R. C. and Pollard, D. D., 1981. Anticrack Model for Pressure. Geol., Vol. 9, pp. 419 - 424.

Georg Mandl, 2005. Rock Joints, the Mechanical Genesis, Springer Berlin Heidelberg New York.221p. 
Hancock, P. L., 1985. Brittle Microtectonics, Principles and Practice, J. Struct., Geol., Vol. 7, pp. 437-457.

Hobbs, B., E. Means, W. D. and Williams, P. F., 1976. An Outline of Structural Geology: John Wiley and Sons. Inc., New York, 571 p.

Jassim S. Z., and Goff J. C., 2006. Geology of Iraq. Published by Dolin, Pargue and Musem, Brno Czech Republic, 337 p.

Mullenax, A. C. and Gray, D. I., 1984. Interaction of Bed-Parallel Stylolite and Extension Veins in Boudinage. J. Struct. Geol., Vol. 6, pp. 63 - 71

Nicolas, A., 1987. Principle of Rock Deformation; D. Reidel Published CO. Netherland, 208p.

Numan, N. M. S. and Al-Azzawi, N. K., 2002. Progressive Versus Paroxysmal Alpine Folding in Sinjar Anticline, Northwestern Iraq. Iraqi Jour. Earth Sci., Vol. 2, No. 2, pp. 59 - 69.

Numan, N. M S. and Al-Azzawi, N. K., 1993. Structural and Geotectonic Interpretation of Vergence Direction of the Anticlines in the Foreland Folds of Iraq. Abhath Al-Yarmouk (Pure Science and Enguneering), Yarmouk University, Jordan, Vol. 2, No. 2, pp. 57 - 73.

Numan, N. M. S., 1997. A plate Tectonic Scenario for the Phanerozoic Succession in Iraqi Jour. Geol. Soc. Iraq, Vol. 30, No. 2.

Numan, N. M. S., 2000. Major Cretaceous Tectonic Events in Iraq. Ref. Jour. Sci., Vol. 11, No. 3, pp. 32 - 52.

Numan, N. M. S., 2001a. Cretaceous and Tertiary Alpine Subductional History in Northern Iraq. Iraqi Jour. Earth Sci., Vol. 1, No. 2, pp. 59 - 74.

Ragan, D. M., 1986. Structural Geology, An Introduction to Geometrical Techniques: John Wiley and Sons, Inc., 196 p.

Ramsay, J. G. and Huber, M. I., 1987. Folds and Fractures: The Techniques of

Modern Structural Geology: 2, Academic Press, New York, 700 p.

Shadmon, A., 2008. Stylolites - A diagnostic tool?

http://www.litosonline.com/articles/73/ar 7304e.shtml, pp. 1 - 9.

Sinha-Roy, S., 2002. Kinetics of Differentiated Stylolite Formation. Current Science., Vol. 8, No. 25, pp. 1038 - 1046.

Suppe, J., 1985. Principles of Structural Geology: Prentice-Hall, Inc., New Jersey, $537 \mathrm{p}$.

Twiss, R. J. and Moores, E. M., 2007. Structural Geology: W.H. Freeman and Company, 41Madison Avenue, New York, 736 p.

Van der Pluijm, B. A. and Marshak, S., 2004. Earth structure: An Introduction to Structural Geology and Tectonics: $2^{\text {nd }}$ ed., W.W. Norton and Company, Inc., Castle House, London, 656 p. 